\title{
Türkiye'de Kısa Vadeli Sermaye Akımlarının İktisadi Dalgalanmalar Üzerindeki Etkileri: Bir Uzun Dönem Kısıtlı SVAR Modeli
}

Şükrü Apaydın*

Hasan Şahin**

Özet

$\mathrm{Bu}$ çalışmada finansal serbestleşme sonrası dönemde kısa vadeli sermaye akımlarının, Türk ekonomisinde gözlemlenen iktisadi dalgalanmalar üzerindeki etkileri araştırılmaktadır. Çalışmada sermaye hareketlerinin etkilerine yönelik kuramsal açıklamalar ele alındıktan sonra, bu kuramların ortaya koyduğu reel döviz kuru mekanizması Uzun Dönem Kısıtlı Yapısal Vektör Otoregresyon (SVAR) modeli ile analiz edilmektedir. Türkiye'nin 1992:Q12007:Q3 üçer aylık verileri çerçevesinde yapılan analizde, kısa vadeli sermaye akımlarının reel kur aracılığıyla ekonominin reel kesiminde önemli dalgalanmalara neden olduğu saptanmıştır.

Anahtar Kelimer

JEL Kodlar

\section{The Effects of Short-term Capital Flows on Economic Fluctuations in} Turkey: A Long-run Restricted SVAR Model
: K1sa Vadeli Sermaye Akımları, İktisadi Dalgalanmalar, Uzun

Dönem Kisıtlar, Yapısal Vektör Otoregresyon Modeli.

: C32; E32; F32

\section{Abstract}

\footnotetext{
* Yrd. Doç. Dr. Nevşsehir Hacı Bektaş Veli Üniversitesi, İỉB, Uluslararası Ticaret Bölümü Üniversitesi, sukruapaydin@ nevsehir.edu.tr

${ }^{* * *}$ Prof. Dr. Ankara Üniversitesi SBF, hsahin@politics.ankara.edu.tr
} 
In this study, effects of short-run capital flows after the time of financial liberalization on the observed business cycles in Turkish Economy have been discussed. In the study, after theoretical approaches on the effects of capital flows had been mentioned, real exchange mechanism which is explained in the related theoretical approaches has been analyzed with a Long-run Restricted Structural Vector Autoregression (SVAR) model. The quarterly data of Turkish Economy included a period of 1992:Q1 to 2007:Q3 have been used in the empirical model. Results of the empirical work show that short-run capital flows by exchange rate cause importantly cycles on real part of economy.
Keywords
: Short-term Capital Flows, Business Cycles, Long-run
Restrictions, Structural Vector Autoregression Model
Jel Classification Codes $\quad$ : C32; E32; F32

\section{Giriş}

1980'li yılların en dikkat çekici konusu, Yeldan (2001: 13) tarafından “ulusal ekonomilerin dünya piyasalarlyla eklemlenmesi ve tüm iktisadi karar süreçlerinin giderek dünya kapitalizminin birikim dinamikleriyle belirlenmesi" olarak tanımlanan "küreselleşme" olgusudur. Bu çerçevede söz konusu dönemdeki en önemli uygulama ise ulusal ekonomilerde özellikle finansal liberalizasyon anlayışına uygun olarak kısa vadeli sermaye hareketlerinin serbestleştirilmesi olmuştur (Öncü, 2008: 744).

Kuşkusuz sermaye hareketlerinin serbestleştirilmesi ilk defa karşılaşılan bir uygulama değildir. Sermaye hareketleri bakımından ilk küreselleşme dönemi, Arrighi’nin İngiliz Hegemonya Dönemi olarak adlandırdığı 1870-1914 Klasik Liberalizm; diğeri ise yine Arrighi’nin Amerikan Hegemonya Dönemi içinde bir dönem olarak değerlendirdiği 1980'li y1lları kapsayan "Neoliberalizm”dir (Arrighi, 2000; Köse ve Öncü, 2003; Yeldan, 2001: 14).

Bununla birlikte sermaye hareketlerinin serbestleştirildiği her iki dönem peş peşe ve belirli aralıklarla yinelenen krizlerin* yaşanmasına da sahne olmuş; her krizin Arrighi'nin (2000)

\footnotetext{
* Mitchell (1951: 43) birinci döneme ilişkin olarak 1873, 1884, 1893, 1903 ve 1907 yıllarında beş büyük kriz yaşandığını ifade etmekte, bunlar1 sırasıyla Jay Cooke Paniği, Demiryolu Paniği, Cleveland Paniği, Zengin Adamın Paniği ve Roosevelt Paniği olarak sınıflandırmaktadır. İkinci dönemde ise başta "yükselen piyasa ekonomileri” olmak üzere bir dizi kriz yaşanmıştır. Bunlardan bazıları 1987 Amerika, 1992-1993 Avrupa, 1994-1995 Meksika ve Türkiye, 1997-1998 Asya, 1998
} 


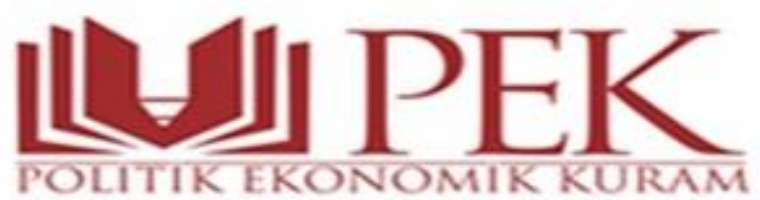

\section{(2017) Cilt 1(1)}

'Sistemik Birikim Daireleri'nde olduğu gibi mali genişleme aşamalarını takip etmesi, sermaye hareketlerinin kriz ve iktisadi dalgalanmalar ${ }^{\dagger}$ üzerindeki etkilerinin tartışılmasına neden olmuştur. Çünkü sermaye girişleri konjonktürün genişleme, sermaye çıkışları ise çöküş aşamasına denk gelmektedir ${ }^{\ddagger}$.

Kriz ve konjonktürel dalgalanmaların nedenleriyle ilgili içsel veya dışsal; parasal, finansal ya da reel; psikolojik, kurumsal veya teknolojik etkenler gibi çok sayıda teori ortaya atılmış; söz konusu teoriler efektif talep yetersizliği, aşırı yatırım, sermaye kıtlığı, parasal, psikolojik etkenler, vb. çok sayıda sınıflandırmaya tabi tutulmuştur ${ }^{\S}$. Bununla birlikte daha yakından ele alındığında, Tanyılmaz'ın (2002: 327) da belirttiği gibi, teorilerin şu sorulara göre şekillendiği söylenebilir. Kapitalist piyasa ekonomilerinin işleyişi nasıldır, piyasa ekonomileri istikrarlı bir yapıya sahip midir? Krizler ve gözlemlenen dalgalanmalar piyasa ekonomisine içsel midir, yoksa bu tür olayların nedeni dışsal etkenler midir? Para ve sermaye hareketlerinin bu süreçlerdeki etkisi nedir? Söz konusu etkenler, hangi mekanizma ya da mekanizmalar aracılığgyla bu dengesizliklere yol açmaktadır?

İktisat teorisi incelendiğinde bu sorulara verilen yanıtlar çerçevesinde konuyla ilgili üç ana yaklaşım göze çarpmaktadır (Shaikh, 2009: 127-128): ${ }^{* *}$

Birinci yaklaşım, her iki küreselleşme dönemine damgasını vuran Klasik iktisat geleneği olarak da ifade edebileceğimiz "Bırakınız yapsınlar" yaklaşımıdır. Smith'in "görünmez el” teoreminden Walras'1n "genel denge" kuramına (Shaikh, 2009: 127-128), Yeni Klasik iktisadın “denge iş çevrimleri” ve "reel konjonktür” kuramlarına kadar bu geleneğe hakim olan anlayış, ekonominin kendini dengeye getirebilen bir mekanizmaya sahip olduğu düşüncesidir. Buna göre kişisel çıkar peşinde koşan, tam bilgi sahibi ve rasyonel bireylerden oluşan bir toplumda, bireysel çıkar arayışı ile toplumsal çıkar arasında var olan "hayran

\footnotetext{
Rusya ve Türkiye, 1999 Brezilya, 2000-2001 Türkiye ve 2002 Arjantin ve nihayet 2007-2008 Dünya Ekonomik Krizleri şeklinde sıralanabilir.

† Çalışmamızda 'business cycles', 'trade cycle' ya da 'macroeconomic fluctuations' kavramlarının karş1lı̆̆ olarak kimi zaman iktisadi dalgalanmalar kimi zaman da konjonktürel dalgalanmalar kavramı kullanılmaktadır.

¥ Bu konuda daha ayrıntılı bilgi için BIS (2009), Bordo (2008), Eichengreen (1999a), Ertürk (2003), Kindleberger (2007), Köse ve Öncü (2003), Tornell ve Westermann (2002), ve UNCTAD (2000) çalışmalarına bakılabilir.

$\S$ Konuyla ilgili olarak Gordon (1961), Haberler (1946), Persons (1926), Schumpeter (1954) ve Zarnowitz’e (1985, 1991) bak1labilir.

${ }^{* *}$ Burada kısaca özetlenen iktisat geleneklerine ve gelenekler içerisinde sınıflandırılabilen iktisat okullarının konuyla ilgili görüş ve düşüncelerinin daha ayrıntılı ve karşılaştırmalı olarak değerlendirmesi için Apaydın (2015a ve 2015b) çalışmalarına bak1labilir.
} 


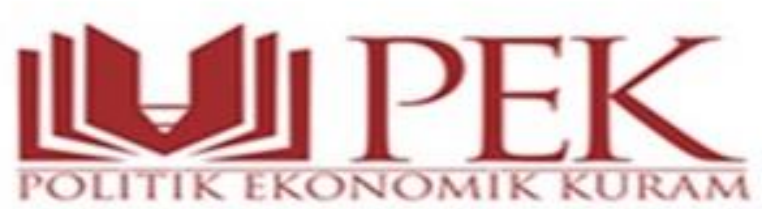

\section{(2017) Cilt 1(1)}

olunacak" bağlantı, piyasa ekonomisine istikrarlı bir yapı kazandırmakta, ekonomi kendiliğinden ve daima tam istihdam düzeyinde dengeye gelmektedir. Kendi haline bırakıldı̆̆ında ekonomide kriz veya konjonktürel dalgalanmalar ortaya çıkmamakta, çıksa bile bunlar geçici 'yol kazaları' olmaktadır. Çünkü piyasanın 'görünmeyen eli' bu tür dengesizlikleri kendiliğinden giderecek şekilde işlemektedir. Buna rağmen dengesizlikler gözleniyorsa, bunun nedeni sisteme dışsal olan etkenlerde aranmalıdır (Blaug, 1978: 59, 153 156; Ricardo, 1817: 120; Schumpeter, 1954: 738; Smith, 1776: 349-350).

Kendiliğinden düzen anlayışıyla birlikte 'her arzın kendi talebini yaratacağına' inanılan, paranın nötr bir değişken ve sermaye getirisinin bir maliyet unsuru olarak ele alındığı bu geleneğin sermaye akımlarına bakış açısı da açıktır: Tam sermaye hareketliliği, sermayenin bol olduğu ülkelerden tasarruf sıkıntısı içindeki ülkelere finansman imkânları yaratacak yurtiçi üretim ve gelirlerin düşük olması durumunda hanehalkı, firmalar ve ülkeler yurtdışından rahatlıkla borçlanabilecek- böylece tüketim ve yatırım harcamaları kesintisiz devam edeceği için hem konjonktürel dalgalanmaların zamanlar arası istikrarı ${ }^{\dagger \dagger}$ sağlanacak hem de sermayenin en etkin ve en verimli alanlara yatırılmasına yol açarak sektörel asimetrileri ortadan kaldırıp ülkelerin rekabet gücünü artıracaktır (Eichengreen, vd., 1999b: 12).

İkinci yaklaşım olarak ele alınabilecek Keynesyen gelenekte ise piyasanın kendiliğinden işleyen mükemmel bir yapıya sahip olmadığı ileri sürülür. Bu yaklaşıma göre kriz ve konjonktürel dalgalanmalar, piyasa mekanizmasının işleyişindeki aksaklıklara bağlı olarak bizzat sistem tarafindan içsel olarak yaratılmaktadır. Belirsizliğin egemen olduğu, geleceğin bilinemediği veya ekonomik birimlerin asimetrik bilgiye sahip olduğu bir dünyada para nötr değildir ve 'her arz kendi talebini yaratmamaktadır', ekonomi efektif talep yetersizliği nedeniyle eksik istihdam düzeyinde dengeye gelmektedir (Davidson, 1990, 1994; Keynes, 1921, 1936, 1937a; Minsky, 1975, 1986, 1992).

Böyle bir yapı altında sermaye hareketleri konjonktür üzerinde önemli ve kalıcı etkilere neden olabilmektedir. Konjonktür sermaye girişleriyle genişlemekte, sermayenin ani çıkışlarıyla daralmaktadır. Bir diğer deyişle, spekülatif faaliyetler uluslararası bir boyut kazanmakta,

\footnotetext{
† Türkçeye düzleştirme olarak da çevrilebilecek smoothing kelimesi yerine.
} 


\section{(2017) Cilt 1(1)}

sermaye hareketliliği istikrarlı bir büyüme yerine istikrarsızlığı artırmaktadır (Arestis ve Glickman, 2002; Davidson, 1998; Dow, 1986-87; Kregel, 1998; Mishkin, 1996, 1998, 1999; Palley, 1999).

Klasik ve Keynesyen geleneklerde kendi haline bırakılan ekonominin kendiliğinden tam veya eksik istihdamda dengede olacağ 1 ileri sürülürken, üçüncü yaklaşım olarak ele alınan Marksizm'de, kriz ve konjonktürel dalgalanmalar (sınai çevrimler) kapitalizmin temel karakteristiği olarak ele alınır ve bu tür dengesizliklerin kapitalist üretimin çelişkili yapısı nedeniyle, kaçınılmaz bir şekilde sürekli olarak yinelendiği ileri sürülür (Mandel, 2008: 151152, 581-582; Marx, 1867: 603-604; Marx, 1894: 221, 433).

Kapitalizmin bu temel karakteristiği, en genel ifadeyle kapitalist üretimin temel amacı ve para-sermayenin özelliklerinden kaynaklanmaktadır. Zira bu geleneğe göre para, hem para hem de sermaye olarak işlev gören kendine özgü, özel bir metadır. Para kendine özgü meta niteliğini, dünya parası, evrensel ödeme ve satın alma aracı ve her türlü servetin evrensel olarak kabul edilen somutlaşmış şekli olarak hizmet ettiği uluslararası boyutta kazanmaktadır (Marx, 1867: 146-149). Kapitalist üretimin temel özelliği ise sermayenin genişleyen yeniden üretimidir, üretime yatırılan sermaye üretimden genişleyerek çıkmaktadır. Bir diğer deyişle amaç, her defasında daha çok kâra, daha çok para-sermayeye sahip olmaktır. Bu durum uluslararası düzeyde de geçerlidir: "Eğer sermaye dişarıya gönderiliyorsa, bu, mutlaka içerde kullanılmadığı için değil, dış bir ülkede daha yüksek kâr oranı ile kullanılabildiği içindir" (Marx, 1894: 226). Ancak sermayenin bu aşırı üretimi veya aynı anlama gelmek üzere aşırı meta üretimi, sermaye üretiminde belirli aralıklarla kesintilere yol açmaktadır: "Kapitalist üretimin gerçek engeli, sermayenin kendisidir. İşte bu sermaye ve onun kendini genişletmesidir ki, üretimin hem çıkış ve hem de sonuç noktası, hem itici gücü hem amacı olarak görünür..." (Marx, 1894: 221). Sonuç olarak Marksizm'e göre ekonomide birbirini izleyen genişleme ve daralmalar, ulusal veya uluslararası kâr oranlarındaki dalgalanmalara bağlı olarak, farklı sermaye türleri arasındaki rekabet sonucu bizzat sermaye hareketlerinden kaynaklanmaktadır. 
Sermaye hareketlerinin serbestleştirilmesinin ardından, 1989 sonrası dönemde, Türkiye'de yaşanan krizlerin nedenlerine yönelik tartışmalar, bu kuramsal açıklamalara paralel olarak iki ana grupta sürdürülmektedir.

Klasik ve Keynesyen gelenekler içinde kabul edilebilecek birinci grupta kriz tartışmaları, makroekonomik temellerin bozukluğu, iktisat politikalarının yanlışlığ uygulanması, ulusal finans sisteminin hantallı̆̆ $\breve{1}_{1}$ gibi nedenler etrafında yürütülmektedir. Bir başka deyişle genişleme-çöküş çevrimleri, başarısız politikalar, piyasa aksaklıkları veya finansal yapının kırılganlığı gibi nedenlerle yaşanmaktadır (Arın, 2003; Boratav, 2000). Bu çerçevede sermaye akımlarının yaşanan dengesizlikleri artırıcı etkide bulunduğu ifade edilmektedir.

Marksist yaklaşıma içinde kabul edilebilecek ikinci grupta ise kriz ve konjonktürel dalgalanmalar, doğrudan sermaye hareketleri ile açıklanmaktadır. Buna göre ekonominin genişleme-patlama-çöküş aşamalarında nedensellik zinciri sermaye girişleriyle başlamakta, sürdürülemezlik algısına bağlı olarak sermaye çıkışı ve krizle son bulmaktadır (Boratav, 2000). $\S \S$

Bu çerçevede Türkiye'de 1989 sonrası dönemde gözlemlenen iktisadi dalgalanmalar üzerinde kısa vadeli sermaye hareketlerinin ne kadar etkili olduğunun belirlenmesi, çalışmamızın temel amacı olarak belirlenmiştir.

Çalışmanın bundan sonraki bölümünde ilk olarak konuyla ilgili ampirik çalışmalar hakkında bilgi verilmektedir. Daha sonra ise çalışmada kullanılan ekonometrik yöntem ve belirtilen yöntem çerçevesinde 1989 sonrası Türkiye ekonomisi analiz edilmektedir. Nihayet sonuç bölümünde genel bir değerlendirme yapılarak çalışma sonlandırılmaktadır.

\footnotetext{
\# Konuyla ilgili oldukça fazla çalışma bulunmakla birlikte bunlardan öne çıkanlar şöyle sıralanabilir: Agenor, vd., (1997); Altunoğlu ve Güloğlu, (2002); Özatay ve Sak, (2002); Özkan, (2003); Uygur, (2001a, 2001b).

$\S \S \mathrm{Bu}$ yaklaşımla ilgili olarak incelenen diğer çalışmalar şunlardır: Akyüz ve Boratav (2002); Balkan, Biçer ve Yeldan (2002); Boratav (1993, 1995, 2001, 2003); Boratav ve Yeldan (2001); Boratav, Türel ve Yeldan (1996); Somçağ (2002); Yeldan (2001).
} 


\section{(2017) Cilt 1(1)}

\section{Ampirik Literatür}

İktisadi dalgalanmaların analizine yönelik iktisat yazını incelendiğinde, konunun iki farklı boyutuyla ele alındığı görülür.

Bunlardan birincisi, ekonomilerde gözlemlenen dalgalanmaların istatistiksel veya biçimlenmiş olguları ortaya konularak konjonktürel bir nitelik taşıyıp taşımadığı araştırılmaktadır. Bu çerçevede çeşitli yöntemler kullanılarak konjonktürün aşamaları, dönüm noktaları, makroekonomik büyüklüklerin eş zamanlılığı (comovement), oynaklığı, yön bakımından çevrimle olan ilişkisi saptanmaktadır. Böylece çevrimle aynı yönlü, dönüm noktası referans değişkenden önce gelen, yüksek oynaklığa sahip bir değişken konjonktürel dalgalanmaların nedeni olarak yorumlanabilmektedir (Alper, 2000; Jiménez, 2001).

İkinci grup çalı̧̧alarda ise iktisadi dalgalanmaların yapısal kaynakları araştırılmaktadır. VAR (Vector Auto-Regression) modelleri temelinde yapılan çalışmalarda, modele bazı önsel kısıtlamalar getirilerek konjonktürel dalgalanmaların ortaya çıkışında her bir değişkenin etkisi ortaya konulmaya çalışılmaktadır (Alper, 2000; Jiménez, 2001).

Türkiye'de konuyla ilgili yapılan çalışmalar incelendiğinde, iktisadi dalgalanmaların her iki açıdan da ele alındığı görülmektedir. Burada seçilmiş bazı çalışmalara değinilmektedir.

Konuyla ilgili olarak Özatay (1986) tarafindan yapılan çalışmada, öncelikle Türkiye ekonomisinde gözlemlenen dalgalanmaların devreleri stokastik ve deterministik yaklaşımlarla saptanarak bu devrelerin dönüm noktaları araştırılmaktadır. Konjonktür devrelerinin referans bir diziyle yansıtıldığ 1 araştırmada, öncü ve çakışı değişkenler belirlenmektedir. Çalışmada mevsimlik etkilerden arındırılmış uzun dönemli trendden sapmalar değişkenlerin konjonktürel kısımları olarak alınmıştır. Parasalcı konjonktür kuramının Granger Nedensellik testiyle sınandığı analizde, para arzından üretime ve üretimden para arzına anlamlı bir ilişki bulunmamıştır.

Oğuz (1995) tarafindan yapılan çalışmada iktisadi dalgalanmalar Reel Konjonktür Kuramına dayalı olarak Yapısal VAR modeli çerçevesinde incelenmektedir. Türk ekonomisinde gözlemlenen dalgalanmalarda arz ve talep şoklarının etkilerinin araştırıldığı çalışmada, 


\section{(2017) Cilt 1(1)}

Blanchard ve Quah (1989) tarafından önerilen uzun dönem çarpanlara ayırma yöntemi benimsenmekte, yani talep şoklarının uzun dönemde etkili olmadı̆̆ı şeklinde ifade edilebilecek belirleme (identification) kısitlaması kabul edilmekte ve arz (verimlilik) şoklarının dalgalanmalar üzerinde daha etkili olduğu sonucuna ulaşılmaktadır. Ayrıca aynı araştırmacı tarafından 1999 yılında yapılan çalışmada Kydland ve Prescott (1990) yöntemiyle Türkiye ekonomisinde 1960-1994 döneminde iktisadi dalgalanmaların biçimlenmiş olguları araştırılmaktadır.

Danışoğlu (1999) tarafından yapılan çalışmada kısa vadeli sermaye hareketlerinin etkileri VAR modeli ile incelenmektedir. 1987-1998 dönemine ait aylık veriler çerçevesinde yapılan araştırmada kısa vadeli sermaye akımlarının faiz oranları aracılığıyla sanayi üretimini nasıl etkilediği araştırılmaktadır. Elde edilen bulgulara göre sermaye hareketlerinin faizler ve sanayi üretimi üzerinde üç, altı ve dokuz aylık gecikmelerle önemli etkiler yarattığı sonucuna varılmaktadir.

Türk ekonomisinin biçimlenmiş olgularının belirlenmesine yönelik bir diğer çalışma Alper (2000) tarafından yapılmıştır. Burada yine Kydland ve Prescott (1990) yöntemi çerçevesinde mevsimsellikten arındırma, doğrusallaştırma ve trendden arındırma işlemi yapıldıktan sonra, değişkenlerin eş zamanlılı̆̆ değerlendirilmektedir. Çalışmada varılan önemli sonuçlardan biri, Türkiye'de kısa vadeli sermaye hareketlerine göre uzun vadeli brüt sermaye girişlerinin konjonktürle aynı yönlü olduğu ve bir çeyreklik dönemle öncü bir rol oynadığıdır.

Çimenoğlu ve Yentürk (2002) tarafından yapılan çalışmada ise kısa vadeli sermaye hareketlerinin etkileri VAR modeli çerçevesinde incelenmektedir. Sermaye hareketlerinin banka kredileri aracılığıyla tüketim ve yatırım harcamaları üzerindeki etkilerinin araştırıldığı bu çalışmada, değişkenler Granger Nedensellik Testiyle değerlendirilmiştir. Elde edilen bulgulara göre sermaye akımlarındaki artışlar reel özel tüketim harcamalarını üç, reel özel yatırım harcamalarını dört çeyreklik gecikmeyle etkilediği bulunmuştur. Böylece sermaye hareketleri öncelikle tüketim daha sonra da üretim aracılığıyla yatırım harcamalarını tetiklediği sonucuna ulaşılmaktadır. Aynı çalışmada elde edilen bulgulardan sonra, sermaye hareketlerinin göreli yatırımlar üzerindeki etkileri, hesaplanan yurtiçi göreli fiyatlar ve göreli 


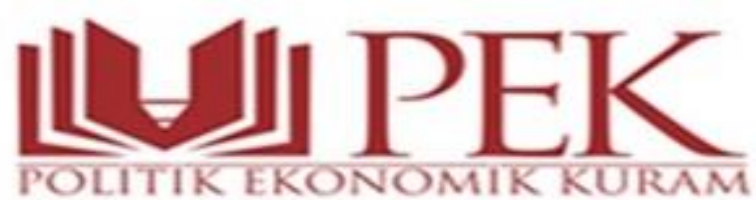

\section{(2017) Cilt 1(1)}

yatırımların sektörel dağılımı çerçevesinde değerlendirilmiştir. Buna göre sermaye hareketlerinin ticarete konu olmayan sektörler lehinde etkileşim ortaya koyduğu sonucuna varılmaktadir.

Sermaye hareketlerinin ekonomik istikrarsızlıklar üzerindeki etkilerini belirlemeye yönelik çalışmalardan biri İnsel ve Sungur (2003) tarafından yapılmıştır. 1989:III-1999:IV dönemine ait üçer aylık verilerle yapılan çalışma beş aşamalı olarak gerçekleştirilmektedir. Öncelikle korelasyon analizinin yapıldığı çalışmada, Granger nedensellik testleriyle her değişken için uyarıcı değişken belirlenmekte, sermaye akımları ile diğer değişkenler arasındaki ilişkinin tahmini En Küçük Kareler (OLS) ve Koşullu Varyans (ARCH/GARCH) yöntemleriyle yapılmaktadır. Nihayet Chow Yapısal Kırılma Testi ile değişkenler arasındaki ilişkinin yapısal kararlılı̆ğ araştırıldıktan sonra bulgular değerlendirilmektedir. Elde edilen bulgular doğrultusunda Türkiye'de ekonomik değişkenlerin kısa vadeli sermaye girişlerinden olumlu, çıkışından olumsuz etkilendiği, ancak değişkenler arasında kalıcı ve kararlı bir ilişkinin olmadığı, dolayısıyla kısa vadeli sermaye hareketlerinin ekonomik dengelerin bozulmasına ve oynaklıkların artmasına neden olduğu sonucuna varılmaktadır.

Son olarak Aslan, vd. (2014) tarafından yapılan çalışmada kısa vadeli sermaye hareketleri ile ekonomik büyüme ve reel döviz kuru arasındaki ilişkiler incelenmiştir. 1998-2011 dönemine ait üçer aylık veriler çerçevesinde yapılan çalışmada, kısa vadeli sermaye hareketleri ile büyüme ve reel döviz kuru arasındaki nedensellik belirlenmeye çalışılmıştır. Buna göre kısa vadeli sermayeden ekonomik büyümeye doğru tek yönlü, kısa vadeli sermaye ile reel döviz kuru arasında çift yönlü bir nedensellik ilişkisi tespit edilmiştir. Etki-tepki analizleri ve varyans ayrıştırmasıyla da desteklenen çalışmada, Türkiye'de alınacak kararlarda kısa vadeli sermaye-reel döviz kuru ilişkisinin göz önünde bulundurulması gerektiği sonucuna ulaşılmıştır.

Görüldüğü gibi iktisadi dalgalanmaların araştırılmasında kısa vadeli sermaye hareketlerinin etkileri kimi çalışmalarda ele alınmazken, bu etkileri dikkate alan çalışmalarda farklı yöntemlerle de olsa sermaye akımlarının ekonomi üzerinde olumsuz etkileri olduğu sonucuna varılmaktadir. 
$\mathrm{Bu}$ çalışmada kısa vadeli sermaye hareketlerinin etkilerinin belirlenmesinde son dönemde yoğun bir şekilde kullanılan Yapısal VAR modeli kullanılmaktadır. Diğer çalışmalardan temel farkı, burada sermaye hareketlerinin reel döviz kuru aracılı̆̆ıla, yani döviz kuru kanalıyla iktisadi dalgalanmalar üzerindeki etkilerinin uzun dönem kısıtlı yapısal VAR yöntemiyle araştırılması oluşturmaktadır. Ayrıca uzun dönem kısıtlı yapısal VAR çalışmalarında yerleşik olarak benimsenen kısıtların yanı sıra uzun dönem kısıtların farklı bir şekilde uygulanması da, çalışmanın söz konusu literatüre bir katkısı olarak ele alınabilecektir.

\section{Ekonometrik Yöntem ve Uygulama}

\section{a. Yapısal Vektör Otoregresyon (Structural Vector Auto Regression - SVAR) Modelleri}

SVAR modelleri Christopher Sims'in 1980 yılında geliştirdiği VAR modellerinden hareketle türetilen modellerdir. VAR modelleri, her bir değişkenin hem kendi gecikmeli değerleri hem de diğer $(n-1)$ değişkenlerin cari ve geçmiş değerleriyle açıklanan $n$ denklemli, $n$ değişkenli doğrusal bir modeldir (Enders, 1995; Stock ve Watson, 2001).

$k$ sayıda içsel değişkenden oluşan ( $k$ boyutlu), maksimum gecikme sayısı $p$ olan ( $p$. dereceden) genel bir SVAR modeli aşağıdaki şekilde gösterilebilir ${ }^{* * *}$ :

$$
A y_{t}=A_{0}+A_{1} y_{t-1}+\cdots+A_{p} y_{t-p}+B \varepsilon_{t}
$$

Burada $y_{t}(k \times 1)$ boyutlu değişkenler (örneğin bu çalışmadaki sıcak para, reel döviz kuru, reel GSYİH veya sektörel üretim) vektörünü; $A_{i}(i=1, \ldots . . p)(k \times k)$ katsayllar matrisini; $A$ değişkenler arasındaki eş anlı ilişkileri gösteren katsayılar matrisini; $B$ artık terimler ile katsayılar arasındaki ilişkiyi gösteren ve diyagonal elemanları sıfırdan farklı matrisi ve $\varepsilon_{t}$ ise ( $k$ x 1) boyutlu yapısal şoklar vektörünü göstermektedir. Burada içsel değişkenlerin durağan, yapısal şokların serisel olarak ilişkisiz ve beyaz gürültü süreçleri oldukları varsayılmaktadır.

SVAR modellerinde değişkenlerin cari değerleri, diğer değişkenler üzerinde eş anlı etkiye sahip oldukları için (1) modelinden doğrudan tahmin yapılamamaktadır. Bu nedenle yapısal

\footnotetext{
*** SVAR modelinin teorik yapısının geliştirilmesinde Enders (1995), Amisano ve Giannini (1997), Breitung, vd. (2004) ile Lütkepohl (2005)'ten faydalanılmıştır.
} 
modelin indirgenmiş biçim formuna dönüştürülmesi gerekir. (1) modelinin her iki tarafi $A^{1}$ ile çarpılırsa standart veya indirgenmiş biçim VAR modeli elde edilmektedir:

$$
A^{-1} A y_{t}=A^{-1} A_{0}+A^{-1} A_{1} y_{t-1}+\cdots+A^{-1} A_{p} y_{t-p}+A^{-1} B \varepsilon_{t}
$$

Burada ${ }_{0}=A^{1} A_{0}, \quad \Gamma_{1}=A^{-1} A_{1}, \quad \Gamma_{p}=A^{-1} A_{p} \quad$ ve $u_{t}=A^{-1} B \varepsilon_{t}$ tanımlamaları yapilırsa indirgenmiş biçim model aşağıdaki gibi olacaktır:

$$
y_{t}=\Gamma_{0}+\Gamma_{1} y_{t-1}+\cdots+\Gamma_{p} y_{t-p}+u_{t}
$$

Yapısal model hata terimleri ile indirgenmiş model hata terimleri (artık terimler) arasındaki bağlantı ise;

$$
u_{t}=A^{-1} B \varepsilon_{t}
$$

ile gösterilmektedir. Buradaki önemli nokta, indirgenmiş biçim modelden elde edilen artık terimleri ile yapısal modeldeki şokların 'bileşik' hale gelmiş olmasıdır. Yani indirgenmiş modelin artık terimleri, değişkenler üzerindeki eşzamanlı dolaylı şokların etkileriyle 'karışmıştır'. Bu bileşik şoklar değişkenlerdeki tahmin hatalarını göstermelerine rağmen, yapısal bir yoruma sahip değillerdir. Bir başka anlatımla, indirgenmiş modelden elde edilen artık terim ve katsayılar, gerçek yapısal katsayı ve şokları yansıtmamaktadır. Enders'a (1995) göre, sadece öngörü ile ilgilenilmesi durumunda öngörü hatalarındaki bileşim önemli değildir. Ancak her bir değişkendeki şokların etkilerini ortaya koymak için etki-tepki fonksiyonları ve varyans ayrıştırması elde edilmek istendiğinde yapısal şokların kullanılması gerekir. $\mathrm{Bu}$ durumda da yapısal şokların ayrıştırılması gerekir.

\section{Belirleme Kısıtları (Identification Restrictions)}

Yapısal şokları ayırt edebilmek için $A$ ve/veya $B$ matrislerine $\left(k^{2}-k\right) / 2$ sayıda kısıt konulmalıdır. Çünkü yapısal şokların varyans-kovaryans matrisi $\left(k^{2}+k\right) / 2$ sayıda bağımsız elemandan oluşmaktadır. A matrisinin birim matris olması durumunda tam tanımlanmış bir sistem için B matrisinin sıfır olmayan elemanları üzerine sıra koşulu (order condition) gereği $\left(k^{2}-k\right) / 2$ 'yi geçmemelidir. 


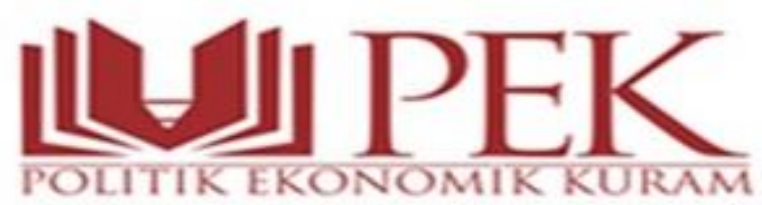

\section{(2017) Cilt 1(1)}

Uygulamada $A$ ve/veya $B$ matrislerine konulan ve kısa dönem kısıtlar çerçevesinde üç tür SVAR modelinden bahsedilebilmektedir.

Gözlemlenebilir değişkenler arasındaki eşanlı veya kısa dönem ilişkileri modellemek amacıyla geliştirilen modellerde, $B$ birim matris iken $A$ matrisi üzerine kısıtlar konulmakta ve bu modeller A Modeli olarak adlandırılmaktadır. B Modeli olarak adlandırılan diğer modelde ise yapısal şokların yorumlanmasına önem verilmekte ve $A$ birim matris iken $B$ matrisine kısıtlar getirilmektedir. Hem $A$ hem de $B$ matrislerine eş anlı olarak kısıt uygulanan $A B$ Modelinde, hem içsel değişkenler arasındaki eşanlı ilişkiler hem şokların etkileri bir arada açıklanabilmektedir. Bu üç modelde $A$ ve $B$ matrislerine getirilen kısıtlar, ilk defa Sims (1980) tarafından geliştirilen ve Cholesky ayrıştırması olarak bilinen yöntemde olduğu gibi yinelemeli veya alt üçgensel bir yapıda olabilmektedir. Ancak bu modellerde yapısal şokların yinelemeli yapısı, mekanik olarak değil teorik belirlemelere uygun olarak ortaya çıkmaktadır. Ayrıca bu modeller, Bernanke (1986) ve Sims (1986) tarafından önerilen yinelemeli olmayan kısıt belirlemelerine de imkan tanımaktadır (Amisano ve Giannini, 1997; Breitung, vd., 2004; Lütkepohl, 2005). ${ }^{\dagger \dagger \dagger}$

Göreli olarak daha yeni çalışmalarda kısa dönem veya eşanlı kısıtlar uygulamak yerine uzun dönem kısıt uygulamaları yapılmaktadır. Blanchard ve Quah (1989) tarafindan yapılan çalışma bu tür SVAR modellerinin en tipik örneğidir. Beveridge ve Nelson (1981) tarafindan önerilen reel GSIYYH'nın geçici ve kalıcı bileşenlerine ayrıştırma yönteminin yeniden ele alındığı bu çalışmada, reel GSYİH’nın nasıl ayrıştırılacağı ve yapısal şokların nasıl elde edileceği gösterilmektedir. $\mathrm{Bu}$ modelin temel avantajı şokların etkilerinin kalıcı olup olmadığının belirlenmesine imkân vermesidir (Blanchard ve Quah, 1989; Enders, 1995).

Enders (1995) izlenerek uzun dönem kısıtlamalı SVAR modeli, üç değişkenli bir model için sabit terimler ihmal edilerek aşağıdaki şekilde gösterilebilir:

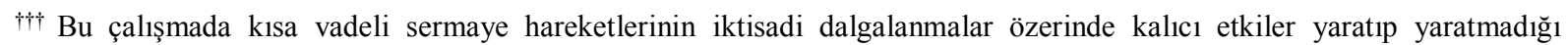
araştırıldığı için uzun dönem kısıtlı SVAR modeli benimsenmiş, bu nedenle kısa dönem kısıtlı modellerle ilgili daha fazla ayrıntıya yer verilmemiştir.
} 


\section{(2017) Cilt 1(1)}

$$
\left[\begin{array}{c}
l s p_{t} \\
d l r d k s_{t} \\
d l g d p s_{t}
\end{array}\right]=\left[\begin{array}{lll}
C_{11}(L) & C_{12}(L) & C_{13}(L) \\
C_{21}(L) & C_{22}(L) & C_{23}(L) \\
C_{31}(L) & C_{32}(L) & C_{33}(L)
\end{array}\right]\left[\begin{array}{l}
\varepsilon_{1 t} \\
\varepsilon_{2 t} \\
\varepsilon_{3 t}
\end{array}\right]
$$

veya daha özet bir gösterimle,

$$
y_{t}=C(L) \varepsilon_{t}
$$

şeklinde ifade edilebilir. Burada $C_{i j}(L)$ uzun dönem etki çarpanlarını göstermektedir ve $\varepsilon_{t}$ her biri sabit varyanslı bağımsız beyaz gürültü süreçleri olan şoklar olarak kabul edilmektedir. Serilerin durağan olduğu varsayımı altında VAR modeli aşağıdaki gibi gösterilmektedir:

$$
\left[\begin{array}{c}
l s p_{t} \\
\text { dlrdks }_{t} \\
\text { dlgdps }_{t}
\end{array}\right]=\left[\begin{array}{lll}
A_{11}(L) & A_{12}(L) & A_{13}(L) \\
A_{21}(L) & A_{22}(L) & A_{23}(L) \\
A_{31}(L) & A_{32}(L) & A_{33}(L)
\end{array}\right]\left[\begin{array}{c}
l s p_{t-1} \\
d l r d k s_{t-1} \\
d l g d p s_{t-1}
\end{array}\right]+\left[\begin{array}{c}
u_{1 t} \\
u_{2 t} \\
u_{3 t}
\end{array}\right]
$$

Daha kısa bir gösterimle:

$$
y_{t}=A(L) y_{t-1}+u_{t}
$$

VAR modelindeki artıklar ile yapısal şoklar arasındaki ilişki ise şu şekilde olmaktadır:

$$
\left[\begin{array}{l}
u_{1 t} \\
u_{2 t} \\
u_{3 t}
\end{array}\right]=\left[\begin{array}{lll}
c_{11}(0) & c_{12}(0) & c_{13}(0) \\
c_{21}(0) & c_{22}(0) & c_{23}(0) \\
c_{31}(0) & c_{32}(0) & c_{33}(0)
\end{array}\right]\left[\begin{array}{l}
\varepsilon_{1 t} \\
\varepsilon_{2 t} \\
\varepsilon_{3 t}
\end{array}\right]
$$


Daha kısa göstermek istediğimizde artık terimler ile yapısal şoklar arasındaki ilişki,

$$
u_{t}=C(0) \varepsilon_{t}
$$

olmaktadır. Burada $C(0)$ şokların değişkenler üzerindeki anlık etkilerini veya kısa dönem etki çarpanlarını göstermektedir. Uzun dönem kısıtlı SVAR modellerinde problem, uzun dönem kısıtların VAR gösterimine transferidir. Bunu kolaylaştırmak için (6) sistemi aşağıdaki gibi yazılabilir:

$$
y_{t}=A(L) L y_{t}+u_{t}
$$

Ayrica $y_{t}=[I-A(L) L]^{-1}$ olduğundan,

$$
y_{t}=A(L) u_{t}
$$

olmaktadır. (7)-(8) ile (4) numaralı denklemler kullanılarak,

$$
\begin{gathered}
y_{t}=A(L) C(0) \varepsilon_{t} \\
C(L)=A(L) C(0)
\end{gathered}
$$

sonucuna ulaşılabilecektir. Böylece uzun dönem kısıtlar kullanılıp ve $A(L)$ tahmin edildikten sonra tam tanımlı SVAR modeli elde edilebilecek, etki-tepki fonksiyonları ile öngörü hatasının varyans ayrıştırması yapılabilecektir. Etki-tepki fonksiyonları, hata terimlerinde meydana gelen şokların zaman içinde değişkenler üzerindeki etkilerini ortaya koymaktadır. Bir başka ifade ile bu fonksiyonlar, şoklar karşısında değişkenlerin gösterdiği tepkilerin zaman patikalarını göstermektedir. Tahminin hata varyans ayrıştırması ise, VAR sistemindeki farklı değişkenlerde meydana gelecek şokların bileşenlerine ayrıştırılmasıdır. Buna göre herhangi bir şok türündeki değişim kendisi veya bir başka serinin hata varyansını hị̧ açıklamıyorsa, bu durumda şoklardan etkilenmeyen değişkenin dışsal olması, diğer değişkenin kendisinden ve o değişkendeki şoklardan bağımsız hareket etmesi söz konusu olmaktadır (Enders, 1995: 311; Lütkepohl, 2005: 52, 64). Böylece ilgili değişkendeki dalgalanmaların nedeni başka etkenlerde aranmaktadır. 


\section{(2017) Cilt 1(1)}

\section{b. Veri Tabanı ve Değişkenler}

Kısa vadeli sermaye hareketlerinin konjonktürel dalgalanmalar üzerindeki etkileri, Türkiye'nin 1992-2007 dönemine ait üçer aylık verilerle analiz edilmiştir. Verilerin 1992 öncesini kapsamamasının nedeni, temel etkisi araştırılan kısa vadeli sermaye hareketlerine ait söz konusu döneme ilişkin ayrıntılı verinin bulunmamasıdır. Verilerin 2007 sonrasını kapsamamasının nedeni ise ülkemizde 2007 yılından sonra GSYİH serisinin 1998 fiyatlarıyla yayınlanmaya başlamasıdır. Yeni GSYİH serisinin sermaye hareketlerinin serbestleştirildiği 1989-1998 dönemini kapsamaması nedeniyle çalışmamızda 1987 yılı fiyatlarıyla GSYİH verileri kullanılmış, ancak bu veriler 2007 yılı sonu itibariyle yayımlanmamaya başlamıştır. Ayrıca üçer aylık verilerin kullanılma nedeni GSYİH'ya ilişkin aylık verilerin ülkemizde sunulmamasıdır. Türkiye’ye ait veriler TCMB Elektronik Veri Dağıtım Sistemi (EVDS) ve Türkiye İstatistik Kurumu internet sitesinden sağlanmıştır. Modelde yapılan ekonometrik testler ve yapılan tahminlerde Eviews 8.0 ve JMulti 4 paket programları kullanılmıştır.

Çalışmada üç değişken kullanılmıştır. Bunlar kısa vadeli sermaye hareketleri, reel döviz kuru ve reel GSYİH'dir.

\section{Kısa Vadeli Sermaye Hareketleri}

$\mathrm{Bu}$ çalışmada da kısa vadeli sermaye hareketleri "sıcak para" kavramına uygun olarak tanımlanmış, IMF'nin ödemeler dengesi sistematiğine uygun olarak düzenlenmiştir. Böylece hisse senetlerine yapılan yatırımlar, bankalara ve diğer sektörlere kısa vadeli krediler, banka ve diğer sektörlerdeki mevduat ve para sıcak para kapsamına alınmıştır. 1992:1 - 2007:3 dönemine ilişkin kısa vadeli sermaye hareketlerinin gelişimi logaritmik olarak aşağıdaki şekilden izlenebilir. 


\section{(2017) Cilt 1(1)}

POLITIK EKONOMIK KURAM

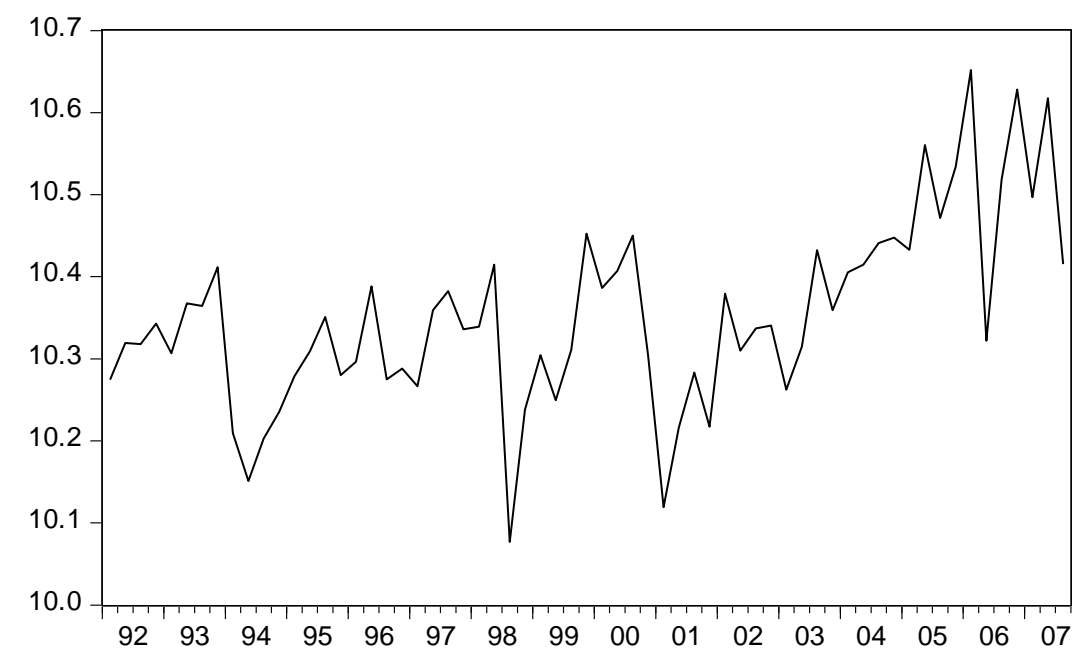

Şekil 1: 1992-2007 Döneminde Kısa Vadeli Sermaye Hareketleri

\section{Reel Döviz Kuru}

Kısa vadeli sermaye hareketlerinin ekonomi üzerindeki etkileri, "döviz kuru kanalı" çerçevesinde araştırıldığı için, çalışmamızda reel döviz kuru önemli bir değişken olarak yer almıştır. Çalışmada TCMB'nin 17 ülke parasını esas alarak tanımladığı tüketici fiyat endeksi bazlı 1995 yılı fiyatlarıyla reel efektif döviz kuru verileri kullanılmıştır. Endeksteki yükselişler TL'nin reel değer artışını, düşüşler reel değer kaybını göstermektedir. Araştırmanın kapsadığı döneme ilişkin reel döviz kuruna ilişkin mevsimsellikten arındırılmış veriler Şekil -2’de gösterilmiştir. 


\section{(2017) Cilt 1(1)}

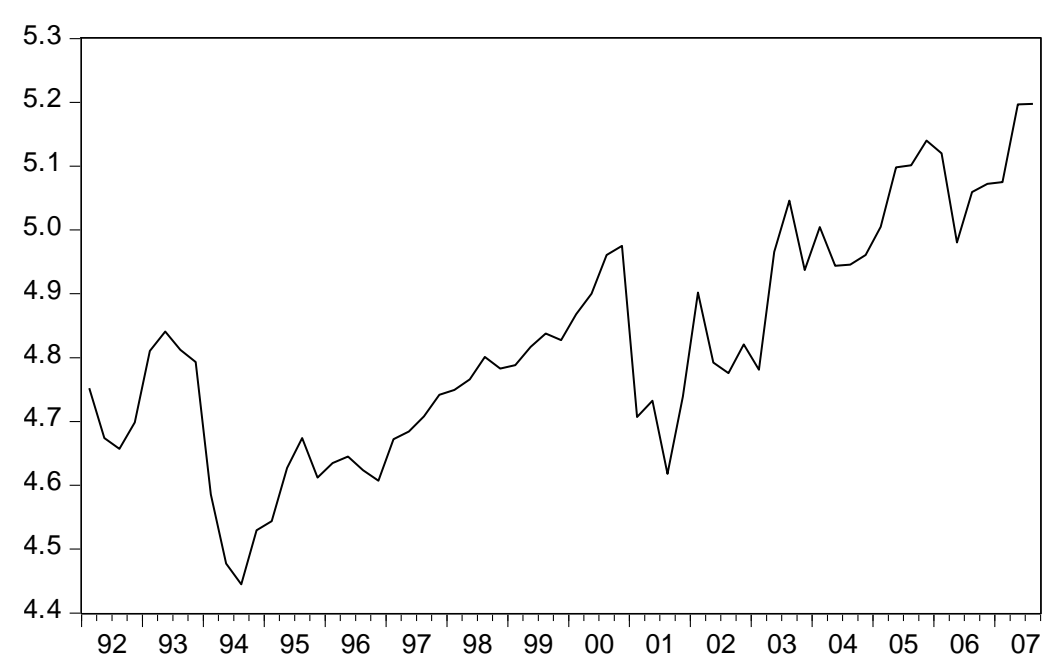

Şekil 2: 1992-2007 Döneminde Reel Döviz Kuru

\section{Reel GSYIH}

Konjonktürel dalgalanmalar analizlerinde temel referans değişken reel GSYİH'dır. Bu nedenle çalışmamızda da temel değişken olarak reel GSYİH alınmıştır. Böylece sermaye hareketlerinin konjonktürel dalgalanmalara neden olup olmadığı, oluyorsa bu etkilerin kalıcı ya da geçici bir özellik gösterip göstermediği test edilmiştir. Değişkenle ilgili olarak TÜİK'in yayınladığı 1987 yılı fiyatlarıyla GSYİH'ya ait zaman serileri kullanılmıştır. Mevsimsellikten arındırılmış veriler Şekil-3'te gösterilmiştir.

Ayrıca çalışmamızda iktisadi dalgalanmalar analiz edildiği ve konjonktürel analizlerde temel referans değişken olduğu için GSYİH'nin konjonktürel özelliği tespit edilmiş ve Şekil-4’te gösterilmiştir. ${ }^{\dagger+\dagger}$

‡¥¥GSYIHH'deki konjonktürel dalgalanmaların belirlenmesinde Hodrick-Prescott filtresi kullanılmıştır. Bu yöntemle önce reel GSYİH'nin trend gelişimi tespit edilmiş, daha sonra bu trend değerler tarihsel olarak gözlemlenen değerlerden çıkartılarak çevrimsel değerler elde edilmiştir. 


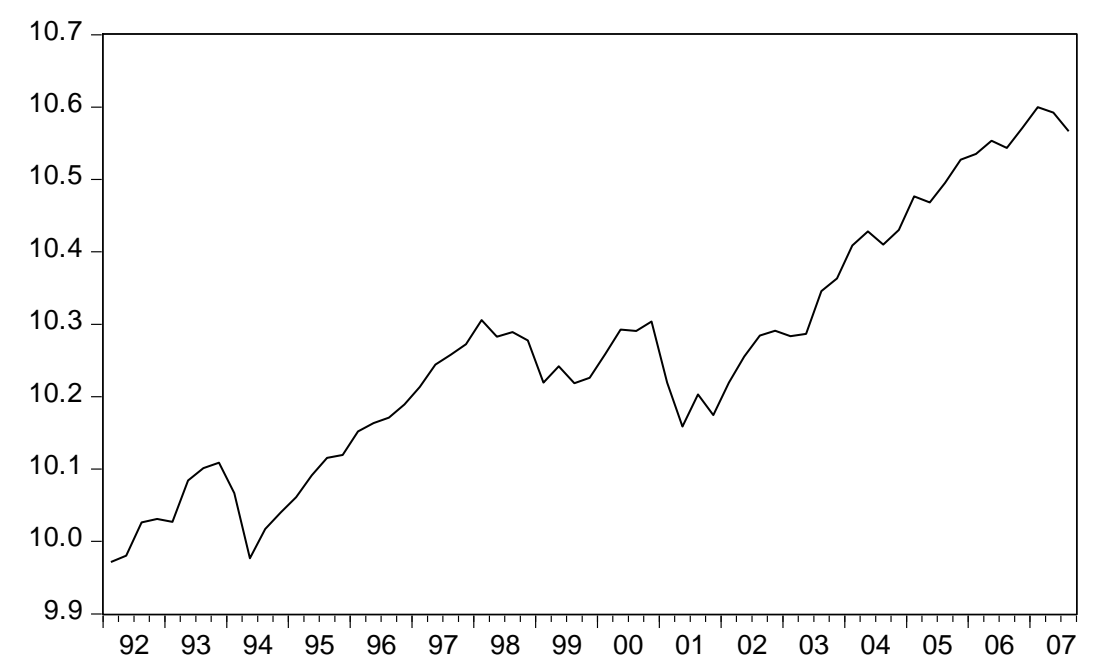

Şekil 3: 1992-2007 Döneminde Reel Gayri Safi Yurtiçi Hâsıla

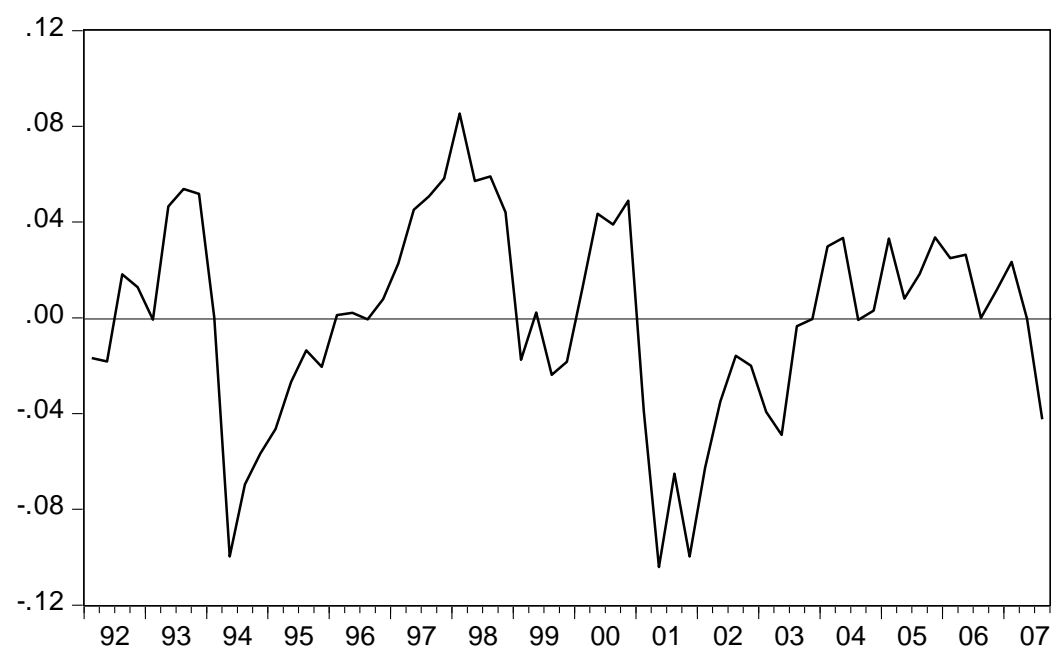

Şekil 4: 1992-2007 Döneminde Konjonktürel Dalgalanmalar

Değişkenlere ait semboller aşağıdaki tabloda gösterilmiştir. Sektörel üretim oranı dışında tüm değişkenlerin logaritmaları alınmış ${ }^{\S \S}$, bu nedenle değişkenlerin önüne "L” harfi eklenmiştir.

§§§ Değişkenlerin dönüştürülme işlemi ya logaritmaları veya birinci farklarının alınması şeklinde yapılmaktadır. Birinci yöntemde trend durağan değişken deterministik trend fonksiyonuna dönme eğilimi gösterirken; ikinci yöntemde fark durağan değişken böyle bir eğilim göstermemekte, trend fonksiyonu etrafında dalgalanma eğilimi göstermektedir (Kadılar, 2000). 


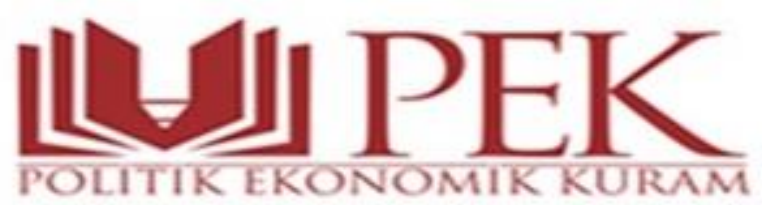

\section{(2017) Cilt 1(1)}

Üretim değerleri X11 yöntemiyle mevsimsellikten arındırılmıştır. Böylece değişkenlerin sembolleri sonundaki "S" harfi ilgili değişkenlerin mevsimsel etkilerden arındırıldığını göstermektedir. Yapılan birim kök testleri sonucunda durağan olmadığı anlaşılan değişkenlerin birinci farklarının alındığını göstermek üzere ilgili değişkenin önüne "D” harfi eklenmiştir. Analizde kullanılan değişkenler ve açıklamalar Tablo-1'de sunulmuştur.

Tablo 1: Analizlerde Kullanılan Değişkenler

\begin{tabular}{|c|l|}
\hline Değişkenler & \multicolumn{1}{|c|}{ Açıklama } \\
\hline DLSP & Kısa Vadeli Sermaye Hareketleri (Milyon Dolar) \\
\hline DLRDKS & Reel Efektif Döviz Kuru Endeksi (1995=100) \\
\hline DLGDPS & Reel GSYïH (1987=100) (Milyon TL) \\
\hline
\end{tabular}

Öte yandan analizlerde sabit terimin yanı sıra Türkiye Ekonomisinin kriz dönemleri dikkate alınarak 1994:Q2 ve 2001:Q1 dönemlerinde “1”, diğer dönemlerde “0” değerini alan D1 kukla değişkeni dışsal değişken olarak kullanılmıştır.

Buraya kadar yaptığımız açıklamalar ışı̆̆ında, model tahmininde aşağıdaki prosedür izlenmiştir:

i) Analizlerde kullanılan değgiskenlerin durağanlık testleri, durağan olmayan değişkenlerin durağanlık derecelerinin belirlenmesi ve durağanlaştırılması,

ii) Aynı dereceden bütünleşik değişkenler için eşbütünleşme analizlerinin yapılması,

iii) Her model için indirgenmiş biçim kısıtsız VAR modelinin tahmin edilmesi ve optimal gecikme sayısının belirlenerek uygunluk testlerinin yapılması ve uygun modelin seçilmesi,

iv) Seçilen VAR modeline yapısal kısıtlar uygulanarak etki-tepki fonksiyonları ile varyans ayrıştırma tahminlerinin yapıllması. 


\section{c. Birim Kök Testleri}

Araştırmamızda durağanlığın test edilmesi amacıyla ampirik çalışmalarda en fazla kullanılan dört birim kök testine yer verilmiştir. Bunun nedeni, her birim kök testinin çeşitli zayıf yönlerinin bir diğer test tarafından dikkate alınmış olmasıdı****

Çalışmada kullanılan birinci test analizlerde en çok tercih edilen Dickey ve Fuller'ın 1979 ve 1981 yıllarında geliştirmiş oldukları Geliştirilmiş Dickey-Fuller (Augmented Dickey-Fuller $\mathrm{ADF})$ testidir. $\mathrm{Bu}$ testlerde zaman serilerinin kendi gecikmeli değerlerinden etkilenmeleri durumunda durağan olmayacakları düşüncesinden hareket edilmektedir. ADF testinin örneklem dağılımı, ilgili serinin bir otoregresyon sürecinden üretilmiş olması varsayımına dayanmaktadır. Ancak çoğu makroekonomik seri, hareketli ortalama (MA) süreci içerebilmekte ve bu sürecin önemli olması halinde otokorelasyonu dikkate almak için daha fazla sayıda gecikmenin modele dahil edilmesi gerekmektedir. Ancak bu durumda da Schewert'in (1989) de belirttiği gibi yapılacak testlerde önemli derecede boyut bozukluğu (size distortion) ortaya çıkmaktadır. ADF testindeki bu yöne dikkat çekmek için PhillipsPerron (PP) testi geliştirilmiştir (Enders, 1995; Güloğlu, 2008).

Phillips-Perron (PP) testinin ADF testinden temel fark1, hata terimlerinin gecikmeli değerlerinin serisel ilişkili (bağımlı) ve değişen varyanslı olarak ele alınmasıdır. Ayrıca ADF testlerinde otokorelasyonu giderebilmek için gecikmeli değerlere yer verilirken, PP testinde sorun test istatistiği modifiye edilerek giderilmeye çalışılmaktadır. $\mathrm{Bu}, \mathrm{PP}$ testinin temel avantajı olsa da hata teriminde büyük ve negatif MA bileşeni olduğunda, yapılan testte önemli boyut bozukluğu veya örneklem çarpıklı̆̆ı ortaya çıkabilmektedir. Bunun yanında sabit terim ve trend içeren testlerin, sadece sabit terim içeren testlere göre test güçlerinin (yanlış bir hipotezin reddedilme olasılığının) azalması nedeniyle, bu durumları göz önüne almak için NgPerron (Ng-P) alternatif birim kök testleri geliştirilmiştir (Güloğlu, 2008). Perron ve Ng (1996) ve Ng ve Perron (2001) tarafından geliştirilen M Testleri olarak adlandırılan bu

\footnotetext{
${ }^{* * * *}$ Söz konusu birim kök testleri ve bu testler arasındaki farklılıklar detaylı bir incelemesi için Enders (1995), Güloğlu (2008), Ng ve Perron (2001), Perron ve Ng (1996), Phillips-Perron (1988), Schwert (1989), Kwiatkowski, Phillips, Schmidt ve Shin (1992) çalışmalarına bakılabilir.
} 


\section{(2017) Cilt 1(1)}

testlerde, $M$ istatistik değerleri kritik değerlerden küçük olduğunda boş hipotez reddedilmektedir.

Kwiatkowski, Phillips, Schmidt ve Shin (1992) tarafından geliştirilen ve isimlerinin baş harfleriyle anılan KPSS testinde ise 'birim köke yakın durağanlık durumunda geleneksel

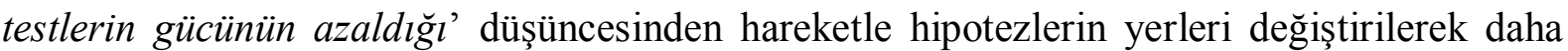
hassas bir test yöntemi geliştirildiği iddia edilir. Burada diğer testlerden farklı olarak boş hipotez trend veya ortalama durağanlık olarak alınmaktadır. Hesaplanan LM istatistiği kritik değerden küçükse durağanlık hipotezi kabul edilmektedir.

Açıklanan nedenlerle değişkenlerin durağanlık analizleri bu dört teste göre yapılmış ve tüm testlerde değişkenlerin optimal gecikme uzunlukları Akaike Bilgi Kriterine (AIC) göre belirlenmiş, test sonucunda durağan olmayan değişkenlerin farkı alınarak birim kök testleri yeniden yapılmıştır. Yapılan dört testin tamamında tüm değişkenler birinci farkları yönünden durağan bulunmuştur (Bkz. Tablo 2, Tablo 3, Tablo 4 ve Tablo 5).

Tablo 2: ADF Birim Kök Testi Sonuçları

\begin{tabular}{|c|c|c|c|c|c|c|}
\hline & \multicolumn{5}{|c|}{ DÜZEY } & \multicolumn{3}{c|}{ 1. FARK } \\
\hline \multirow{2}{*}{ Değişkenler } & $\begin{array}{c}\text { Test } \\
\text { Biçimi* }\end{array}$ & ADF ist. & KD** (\%5) & Test & ADF ist. & KD** (\%5) \\
\hline LSP & $(3, c)$ & $\mathbf{- 2 , 1 8 9 3 4}$ & $-2,91173$ & $(5, c)$ & $-4,94003$ & $-2,91451$ \\
\hline LRDKS & $(4, c)$ & $\mathbf{0 , 2 0 5 2 2}$ & $-2,91263$ & $(3, c)$ & $-6,871676$ & $-2,91263$ \\
\hline LGDPS & $(0, c)$ & $-\mathbf{0 , 5 7 6 9 6}$ & $-2,90920$ & $(3, c)$ & $-4,917821$ & $-2,91263$ \\
\hline${ }^{* *}$ Parantez içinde kullanılan ifadeler sırasılyla gecikme sayısı, sabit terim ve trendi temsil etmektedir. \\
***MacKinnon (1996) kritik değerlerini temsil etmektedir. \\
\hline
\end{tabular}


Tablo 3: PP Birim Kök Testi Sonuçları

\begin{tabular}{|c|c|c|c|c|c|c|}
\hline & \multicolumn{3}{|c|}{ DÜZEY } & \multicolumn{3}{c|}{ 1. FARK } \\
\hline \multirow{2}{*}{ Değişkenler } & $\begin{array}{c}\text { Test } \\
\text { Biçimi* }\end{array}$ & $\boldsymbol{t}$ ist. & $K D^{* *}(\% 5)$ & Test & $\boldsymbol{t}$ ist. & $K D^{* *}(\% 5)$ \\
\hline LSP & $(-)$ & $\mathbf{0 , 2 3 1 1 4}$ & -1.94616 & $(-)$ & -11.9127 & $-1,94625$ \\
\hline LRDKS & (c) & $\mathbf{- 1 . 1 0 9 4 0}$ & $-2,90920$ & (c) & -7.81254 & $-2,91001$ \\
\hline LGDPS & (c) & $\mathbf{- 0 . 6 2 3 2}$ & $-2,90920$ & (c) & -6.85101 & $-2,91001$ \\
\hline * Parantez içinde kullanılan ifadeler sirasılyla sabit terim ve trendi temsil etmektedir. & \\
*** MacKinnon (1996) kritik değerlerini temsil etmektedir.
\end{tabular}

Tablo 4: KPSS Birim Kök Testi Sonuçları

\begin{tabular}{|c|c|c|c|c|c|c|}
\hline & \multicolumn{3}{|c|}{ DÜZEY } & \multicolumn{3}{|c|}{ 1. FARK } \\
\hline Değişkenler & $\begin{array}{c}\text { Test } \\
\text { Biçimi* }\end{array}$ & LM ist. & $\begin{array}{l}K D^{* *} \\
(\% 5)\end{array}$ & $\begin{array}{c}\text { Test } \\
\text { Biçimi* }\end{array}$ & LM ist. & $\begin{array}{l}K D^{* *} \\
(\% 5)\end{array}$ \\
\hline$L S P$ & (c) & 0,6840 & 0,4630 & (c) & 0,0320 & 0,4630 \\
\hline LRDKS & (c) & 0,8364 & 0,4630 & (c) & 0.1086 & 0,4630 \\
\hline LGDPS & (c) & 0.9043 & 0,4630 & (c) & 0.0649 & 0,1460 \\
\hline * Parantez içinde & nilan if & sabit terim & endi tems & tmektedir. & & \\
\hline
\end{tabular}


Tablo 5: Ng-P Birim Kök Testi Sonuçları

\begin{tabular}{|c|c|c|c|c|c|c|c|c|c|}
\hline & & \multicolumn{4}{|c|}{ DÜZEY } & \multicolumn{4}{|c|}{ 1. FARK } \\
\hline Değişkenler & & $M Z a$ & MZt & $M S B$ & MPT & $M Z a$ & MZt & MSB & MPT \\
\hline \multirow[t]{2}{*}{$L S P$} & $\begin{array}{c}t \text { değeri** } \\
(2, c)\end{array}$ & $-5,934$ & $-1,6744$ & 0,2821 & 4,280 & $-56,029$ & $-5,194$ & 0,0927 & 0,67 \\
\hline & $K D^{* *}$ & -8.1 & -1.98 & 0.233 & 3.17 & -8.1 & -1.98 & 0.233 & 3.17 \\
\hline \multirow[t]{2}{*}{ LRDKS } & $\begin{array}{c}\text { t değeri * } \\
(4, c, t)\end{array}$ & -4.538 & -1.3885 & 0.3059 & 19.206 & -218.94 & -10.461 & 0.0477 & 0.42 \\
\hline & $K D^{* *}$ & -17.3 & -2.91 & 0.168 & 5.48 & -17.3 & -2.91 & 0.168 & 5.48 \\
\hline \multirow[t]{2}{*}{ LGDPS } & $\begin{array}{c}t \text { değeri * } \\
(0, c, t)\end{array}$ & -7.055 & -1.8659 & 0.2644 & 12.933 & -1076.6 & -23.197 & 0.0215 & 0.09 \\
\hline & $K D^{* *}$ & -17.3 & -2.91 & 0.168 & 5.48 & -17.3 & -2.91 & 0.168 & 5.48 \\
\hline
\end{tabular}

Yapılan tüm birim kök testlerinde değişkenlerin tamamı düzey değerlerde durağan olmadıkları, birim kök içerdikleri tespit edilmiş, değişkenlerin birinci farklarının birim kök içermedikleri görülmüştür.

\section{d. Eşbütünleşme Analizi}

Birim kök testleri zaman serilerinin durağan olup olmadıklarını, durağan değillerse hangi dereceden bütünleşik olduklarını ortaya koyar. Herhangi bir seri birinci farkı alındıktan sonra durağan hale geliyorsa, değişkenin birinci dereceden bütünleşik olduğu söylenir ve I(1) biçiminde gösterilir. Tek tek ele alındıklarında durağan olmayan seriler, birlikte ele alındıklarında uzun dönemli bir ilişkiye sahip olabilmektedir. Bu durumda değişkenlerin farkı alınmadan önce eşbütünleşme testlerine tabi tutulması gerekir (Kadılar, 2000). Aksi halde değişkenler arasındaki ilişki sahte regresyon özelliği gösterebilecektir. Çalışmamızda değişkenler arasında eşbütünleşmenin olup olmadığı Johansen (1988) ve Johansen ve Juselius (1990) tarafından geliştirilen yöntem kullanılmıştır. 
Maksimum olabilirlik yöntemine dayanan Johansen Yöntemi, özellikle ikiden fazla değişken söz konusu olduğunda çok daha güvenilir sonuçlar vermekte; durağan olmayan serilerde eşbütünleşik vektörlerin sayısı ile bu vektörlerin elemanlarına yönelik hipotez testlerinin yapılmasına imkân tanımaktadır (Civcir, 2005).

VAR temeline dayalı Johansen yönteminde değişkenler arasındaki eşbütünleşme ilişkilerinin testinde, eşbütünleşik vektörlerin sayısının belirlenmesinde iz (trace) ve maksimum özdeğer (maximum eigenvalue) testleri olarak bilinen iki olabilirlik istatistiği kullanılmaktadır. Testlere ilişkin kritik değerler Johansen ve Juselius (1990) tarafından tablolaştırılmıştır. Hesaplanan değerlerle kritik değerler karşılaştırılarak eşbütünleşik vektör sayısı belirlenmektedir. Test istatistikleri kritik değerlerden küçük iken eşbütünleşme ilişkisinin olmadığını ifade eden yokluk hipotezi kabul edilmektedir.

Tablo 6: Eşbütünleşme Analiz Sonuçları

\begin{tabular}{|c|c|c|c|c|}
\hline Hipotez & Eigenvalue & 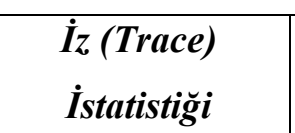 & $\begin{array}{c}\text { Kritik Değer } \\
(0,05)\end{array}$ & Olasilık $^{* * *}$ \\
\hline Eş Bütünleşme Yoktur & 0,2954 & 26,5884 & 29,7970 & 0,1121 \\
\hline $\begin{array}{c}\text { En Fazla Bir Eşbütünleşme } \\
\text { Vardır }\end{array}$ & 0,0978 & 6,6276 & 15,4947 & 0,6213 \\
\hline $\begin{array}{c}\text { En Fazla İki Eşbütünleşme } \\
\text { Vardır }\end{array}$ & 0,0132 & 0,7579 & 3,8414 & 0,3840 \\
\hline Hipotez & Eigenvalue & $\begin{array}{c}\text { Özdeğer (Max- } \\
\text { Eigen) İstatistiği }\end{array}$ & $\begin{array}{c}\text { Kritik Dĕger } \\
(0,05)\end{array}$ & Olasilık $^{* * *}$ \\
\hline Eş Bütünleşme Yoktur & 0,2954 & 19,9608 & 21,1316 & 0,0723 \\
\hline $\begin{array}{c}\text { En Fazla Bir Eşbütünleşme } \\
\text { Vardır }\end{array}$ & 0,0978 & 5,8697 & 14,2646 & 0,6300 \\
\hline $\begin{array}{c}\text { En Fazla İki Eşbütünleşme } \\
\text { Vardır }\end{array}$ & 0,0132 & 0,7579 & 3,8414 & 0,3840 \\
\hline \multicolumn{5}{|c|}{ "İşareti 0,05 düzeyinde hipotezin reddedildiğini göstermektedir. } \\
\hline
\end{tabular}


Bu çerçevede kısa vadeli sermaye, reel döviz kuru ve GSYİH arasındaki ilişkilerin incelendiği modele ilişkin eşbütünleşme testi sabit terimli ancak trendin yer almadığı varsayımına dayalı olarak yapılmış, test sonuçları Tablo-6' da özetlenmişti. ${ }^{\dagger \dagger \dagger \dagger}$

Tablodan da görülebileceği gibi modelde yer alan değişkenler arasında eşbütünleşme ilişkisi tespit edilmemiştir. $\mathrm{Bu}$ nedenle yapısal VAR analizinde tüm değişkenler birinci farkları alınarak modellenmiştir.

\section{e. Uygulama}

VAR modelleriyle yapılan tahminlerin doğru sonuçlar vermesi, model için optimal gecikme sayısının belirlenmesi ve istikrar koşullarının sağlanmasına bağlıdır. Eğer gecikme sayısı uygun şekilde belirlenmemişse, modelin serbestlik derecesi ve diğer tanısal sorunlarla karşılaşmak kaçınılmaz olabilmektedir. Bu nedenle modelin tahmin edilmesinden önce optimal gecikme sayısı belirlenmiş ve diğer uygunluk testleri yapılmıştır.

\section{1) Optimal Gecikme Uzunluğunun Belirlenmesi ve Uygunluk Testleri}

Modelin gecikme sayısı Eviews 8.0 programında yer alan gecikme sayısı seçme kriterine göre yapılmış, sonuçlar Tablo-7'de sunulmuştur. Tablodaki (*) işaretli olan değerler uygun gecikme sayısını göstermektedir.

\footnotetext{
†i†广 Eşbütünleşme analizi ayrıca eşbütünleşme denkleminde sabit terimli fakat trend içermediği buna karşın VAR sisteminde sabit terimin yer aldığı, eşbütünleşme denklemi hem trendli hem de sabit terimli ancak VAR sisteminde sabit terimin yer almadığı varsayımları altında da yapılmıştır. Ancak bu iki varsayım altında da eşbütünleşme ilişkisi tespit edilmemiştir.
} 


\section{(2017) Cilt 1(1)}

Tablo 7: Model 1 Optimal Gecikme Uzunluğu

\begin{tabular}{|c|c|c|c|c|c|}
\hline Gecikme & LR & FPE & AIC & SC & HQ \\
\hline 0 & NA & $3.67 e-08$ & -8.607871 & $-8.388889 *$ & -8.523189 \\
\hline 1 & 25.19675 & $3.08 \mathrm{e}-08$ & -8.784534 & -8.237079 & -8.572828 \\
\hline 2 & 28.28875 & $2.35 \mathrm{e}-08$ & -9.059149 & -8.183222 & -8.720421 \\
\hline 3 & 20.13591 & $2.08 \mathrm{e}-08$ & -9.189511 & -7.985111 & -8.723759 \\
\hline 4 & $\mathbf{1 9 . 3 9 4 1 3 *}$ & $\mathbf{1 . 8 3 e - 0 8 *}$ & -9.335266 & -7.802393 & $-\mathbf{- 8 . 7 4 2 4 9 1 *}$ \\
\hline 5 & 13.48681 & $1.83 \mathrm{e}-08$ & $-9.362909 *$ & -7.501563 & -8.643111 \\
\hline 6 & 9.100066 & $2.05 \mathrm{e}-08$ & -9.295638 & -7.105820 & -8.448818 \\
\hline 7 & 2.933077 & $2.75 \mathrm{e}-08$ & -9.060024 & -6.541733 & -8.086180 \\
\hline
\end{tabular}

Buna göre LR, FPE ve HQ uygun gecikme sayısının 4 olacağını gösterirken SC 0 ve AIC 5 gecikmeyi işaret etmektedir. 5 gecikmeyle yapılan tahminde değişkenlerin katsayıları ile önemle ölçüde anlam kayıpları yaşandığı için, model LR, FPE ve HQ kriterleri çerçevesinde 4 gecikmeyle tahmin edilmiştir. ${ }^{+* t \$}$

Tahmin edilen VAR modelinin uygunluğunu belirleyebilmek için durağanlık ve otokorelasyon testleri yapılmış test sonuçları aşağıda gösterilmiştir.

Otoregresif birim kök testiyle sınadığımız istikrar/durağanlık testi sonucunda tüm karakteristik kökler birim çember içinde yer aldığ için tahmin edilen VAR sistemi durağandır (Şekil 5).

WH Söz konusu modele ilişkin gecikme sayısının tespiti JMulti 4 programıla da test edilmiş AIC, FPE ve HQ kriterleri uygun gecikme sayısının 4 olacağını gösterirken, SC yine gecikme sayısını 0 olarak vermiştir. 


\section{(2017) Cilt 1(1)}

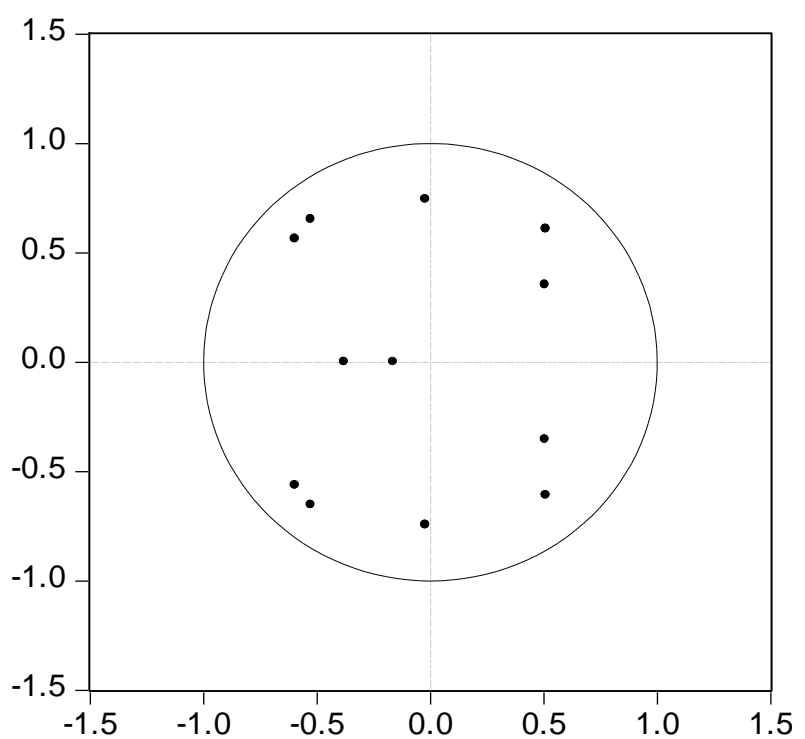

Şekil 5: Otoregresif Birim Kök Testi

VAR sistemindeki hata terimlerinin otokorelasyon içerip içermediği Lagrange Çarpan Testiyle kontrol edilmiştir. Burada boş hipotez belirtilen gecikmede otokorelasyonun olmadığ1 şeklindedir. Olasılık değeri tüm istatistik değerleri için 5. gecikmeye kadar \%5 anlamlılık düzeyinden büyük değerler aldığı için boş hipotez kabul edilmiş, hata terimleri arasında otokorelasyon olmadığı sonucuna ulaşılmıştır (Tablo 8). 


\section{(2017) Cilt 1(1)}

Tablo 8: Lagrange Çarpan Testi Sonuçları

\begin{tabular}{|c|c|c|}
\hline Gecikme & $\begin{array}{c}\text { LM } \\
\text { İstatistiği }\end{array}$ & Olasılık \\
\hline 1 & 7.781399 & 0.5563 \\
\hline 2 & 12.58896 & 0.1821 \\
\hline 3 & 8.922890 & 0.4444 \\
\hline 4 & 6.385787 & 0.7008 \\
\hline 5 & 8.676315 & 0.4677 \\
\hline 6 & 4.102386 & 0.9045 \\
\hline 7 & 2.176986 & 0.9883 \\
\hline 8 & 5.545300 & 0.7844 \\
\hline 9 & 12.99788 & 0.1627 \\
\hline 10 & 7.768739 & 0.5576 \\
\hline 11 & 8.274513 & 0.5067 \\
\hline 12 & 16.13904 & 0.0640 \\
\hline
\end{tabular}

Son olarak değişen varyanslılık sınamasında boş hipotezin sabit varyansı ifade ettiği White testi uygulanmış, burada da olasılık değeri anlamlılık düzeyi \%5'ten büyük olduğu için (0,7802) değişen varyans sorunu olmadığına karar verilmiştir (Tablo 9).

Tablo 9: White Testi Sonucu

\begin{tabular}{|c|c|c|}
\hline $\boldsymbol{X}^{\mathbf{2}}$ & $\begin{array}{c}\text { Serbestlik } \\
\text { Derecesi }\end{array}$ & Olasılık \\
\hline 136.3789 & 150 & 0.7802 \\
\hline
\end{tabular}

2) Uzun Dönem Kısıtı SVAR Tahminleri, Etki-Tepki Fonksiyonları ve Varyans Ayrıştırması

Çalışmamızın bu bölümünde sıcak paranın etkileri, uzun dönem kısıtlı SVAR modeli çerçevesinde iki senaryo etrafinda analiz edilmiştir. 


\section{(2017) Cilt 1(1)}

Birinci senaryo, Keynesyen ve Marksist gelenekler çerçevesinde şekillendirilmiştir. Buna göre, sıcak paranın uzun dönemde hem reel döviz kuru hem de GSYİH'yı etkilediği, buna karşın sıcak paranın uzun dönemde sadece kendi şoklarından etkilendiği varsayılmıştır. Söz konusu senaryo, teorik yapısını yukarıda özetlediğimiz Blanchard-Quah yöntemi çerçevesinde analiz edilmiştir.

İkinci senaryo ise, Klasik gelenekte ileri sürülen Klasik dikotomi anlayışı çerçevesinde oluşturulmuştur. Böylece model, sıcak paranın uzun dönemde reel kur ve GSYİH'yı etkilemediği, GSYİH'nın sadece reel kur şoklarından etkilendiği kabul edilerek belirlenmiştir.

\section{Senaryo I}

Keynesyen ve Marksist geleneklere uygun olarak belirlenen kısıtlar çerçevesinde, uzun dönem kısıtlı SVAR modeli aşağıdaki gibi gösterilebilir:

$$
\left[\begin{array}{c}
l s p_{t} \\
\text { dlrdks }_{t} \\
\text { dlgdps }_{t}
\end{array}\right]=\left[\begin{array}{ccc}
C_{11}(L) & 0 & 0 \\
C_{21}(L) & C_{22}(L) & 0 \\
C_{31}(L) & C_{32}(L) & C_{33}(L)
\end{array}\right]\left[\begin{array}{c}
\varepsilon_{1 t} \\
\varepsilon_{2 t} \\
\varepsilon_{3 t}
\end{array}\right]
$$

Buna göre; reel kararlardan bağımsız süreçler olduğu için kısa vadeli sermaye hareketlerinin uzun dönemde sadece kendi şoklarından etkilendiği varsayılmıştır. Ayrıca reel kurun sadece sıcak para ve kendi şoklarından etkilendiği kabul edilirken; GSYİH serilerinin hem sıcak para hem de reel kur şoklarından etkilendiği varsayılmıştır.

$\mathrm{Bu}$ çerçevede hesaplanan kısa $[C(0)]$ ve uzun dönem $[C(L)]$ etki-tepki fonksiyonları matris formunda aşağıdaki gibi gösterilebilir:

$$
C(0)=\left[\begin{array}{c}
\varepsilon_{s p} \\
d l s p_{t} \\
d l r d k s_{t} \\
\text { dlgdps }_{t}
\end{array}\right]=\left[\begin{array}{ccc}
0.0702 & 0.0089 & -0.0049 \\
0.0054 & 0.0556 & 0.0000 \\
0.0045 & 0.0004 & 0.0182
\end{array}\right]
$$




\section{(2017) Cilt 1(1)}

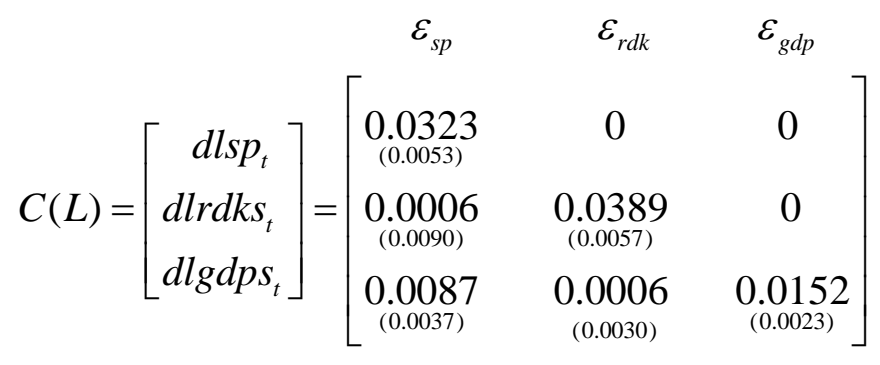

Buna göre kısa vadeli sermaye hareketleri kendi şoklarına hem kısa hem de uzun dönemde pozitif yönde tepki verirken, reel döviz kurunun hem kısa hem de uzun dönemde yükselmesine, yani TL'nin değer kazancına neden olmaktadır. Sıcak para şokları GSYİH’yı hem kısa hem de uzun dönemde pozitif yönde etkilemektedir. Reel kurdaki yükselme TL'nin değer artışını gösterdiğine göre, sıcak paranın reel kur üzerindeki etkileri beklenen yöndedir. Böylece kısa dönem kısıtlı modelde olduğu gibi, sıcak para girişleri hem doğrudan hem de TL'yi değerlendirerek reel kur aracılığıyla GSYİH'yı artırmakta, konjonktürün genişlemesine yol açmaktadır. Yine reel kura göre kısa vadeli sermayenin GSYİH üzerindeki etkisi daha büyük olmaktadır.

Öte yandan reel kurdaki şoklarla GSYİH arasında hem kısa hem de uzun dönemde doğru orantılı bir ilişki vardır. Buna göre reel kurdaki yükselişler GSYİH'nın artmasına neden olurken, reel kurun düşmesi GSYİH'yı düşürmektedir. Bir diğer deyişle yerli paranın değerlenmesi ekonomiyi olumlu yönde etkilerken; değer kayıplarına paralel olarak GSYİH olumsuz etkilenmektedir. Değişkenler arasındaki ilişkilere dair bu söylenenler, tepki fonksiyonları aracılığıyla grafiksel olarak aşağıdaki şekilde gösterilebilir.

Şekil 6'dan görülebileceği gibi, GSYİH kısa vadeli sermaye şoklarına pozitif yönde tepki göstermekte ve yaklaşık 16 çeyreklik bir dalgalanma sonrasında yeni denge değerlerine ulaşmaktadır. Bir diğer ifade ile kısa vadeli sermaye girişleri ekonomik büyüme üzerinde uzun dönemli kalıcı etkilere sahiptir. 
(2017) Cilt 1(1)

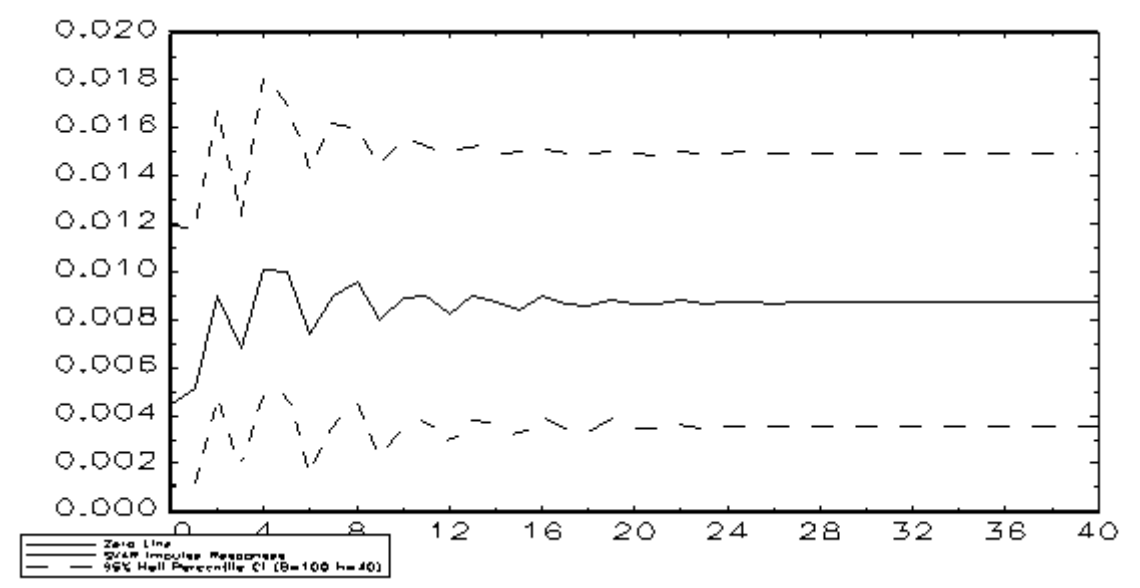

Şekil 6: GSYİH'nın Kısa Vadeli Sermaye Şoklarına Tepkisi (Senaryo I)

Benzer şekilde reel döviz kuru şokları da GSYİH üzerinde kalıcı etkilere sahip olmakla birlikte, sıcak paraya göre bu etkiler çok daha küçüktür. GSYİH reel kur şoklarına ilk dört çeyrekte görece daha sert tepki gösterirken, bu tepkiler yaklaşık 12 çeyrek yıl sonra hafiflemekte ve yeni denge değerlere ulaşılmaktadır (Şekil 7).

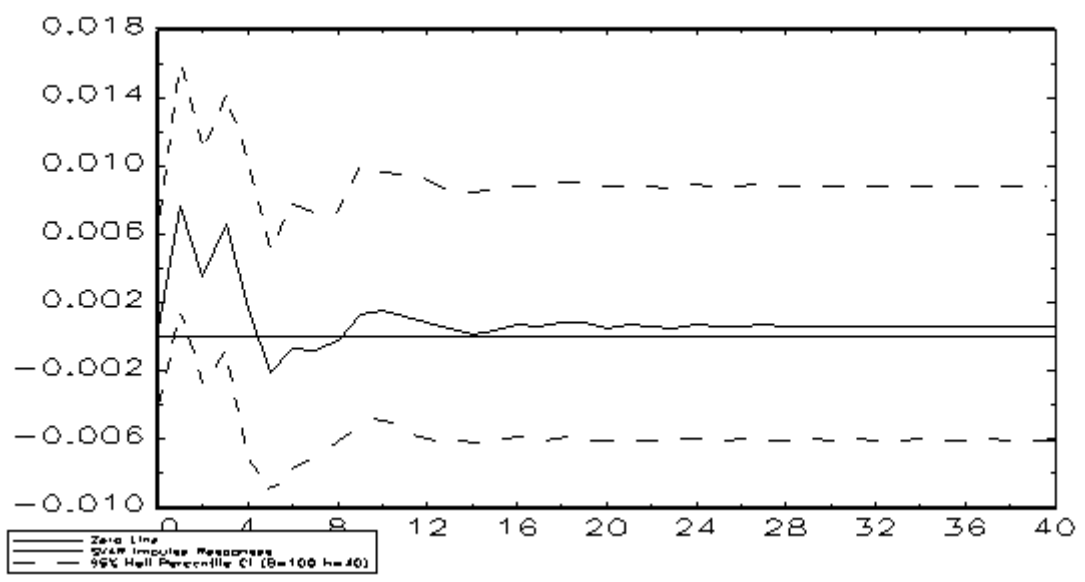

Şekil 7: GSYİH'nın Reel Döviz Kuru Şoklarına Tepkisi (Senaryo I) 


\section{(2017) Cilt 1(1)}

Reel döviz kuru kısa vadeli sermaye şoklarına ilk çeyrekte pozitif ve fakat düşme yönünde tepki verirken, bu tepkiler ikinci çeyrekten itibaren artış yönüne dönmekte ve dalgalı bir seyir izlemektedir. İlk sekiz çeyrekte görece şiddetli bir dalgalanma gözlenirken, bu dalgalanmalar daha sonra hafiflemekte ve yirminci çeyrekten sonra sönme eğilimine girmektedir (Şekil 8). Diğer bir ifade ile reel döviz kurunun kısa vadeli sermaye hareketlerine ilk dönemlerde daha duyarlı olduğu söylenebilir.

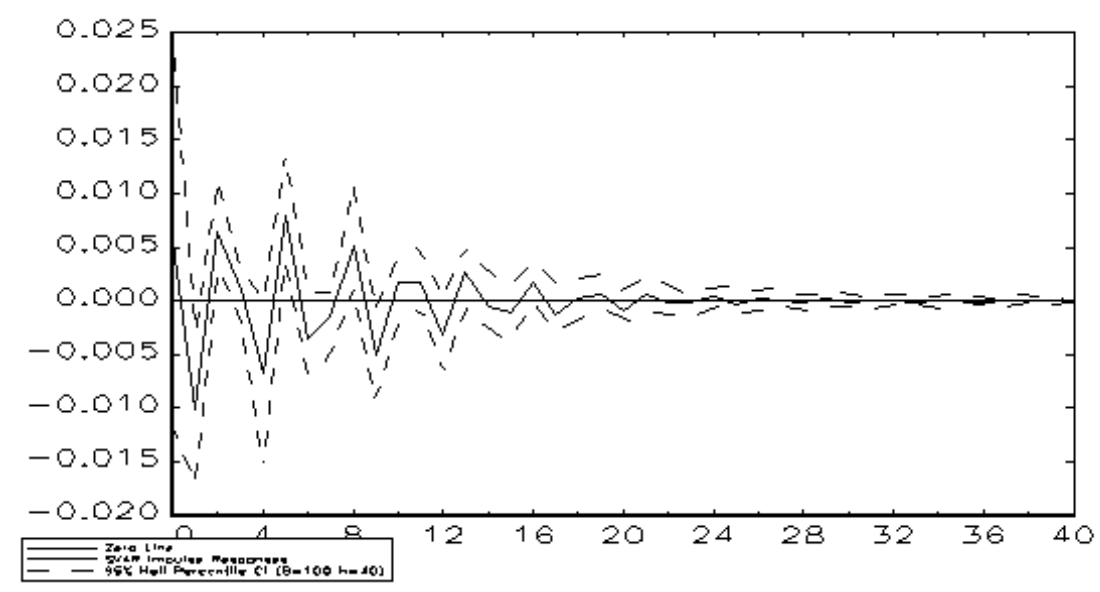

Şekil 8: Reel Döviz Kurunun Kısa Vadeli Sermaye

\section{Şoklarına Tepkisi (Senaryo I)}

GSIYH şokları da reel kur üzerinde benzer etkiler ortaya koymakla birlikte, ilk dönemden itibaren pozitif ve artış yönünde etkiler ortaya çıkmakta ve dalgalı bir seyir gözlenmektedir. Şokların etkisi burada da uzun sürmekle birlikte, kısa vadeli sermaye şoklarına göre etkilerin daha küçük olması söz konusudur (Şekil 9). 


\section{(2017) Cilt 1(1)}

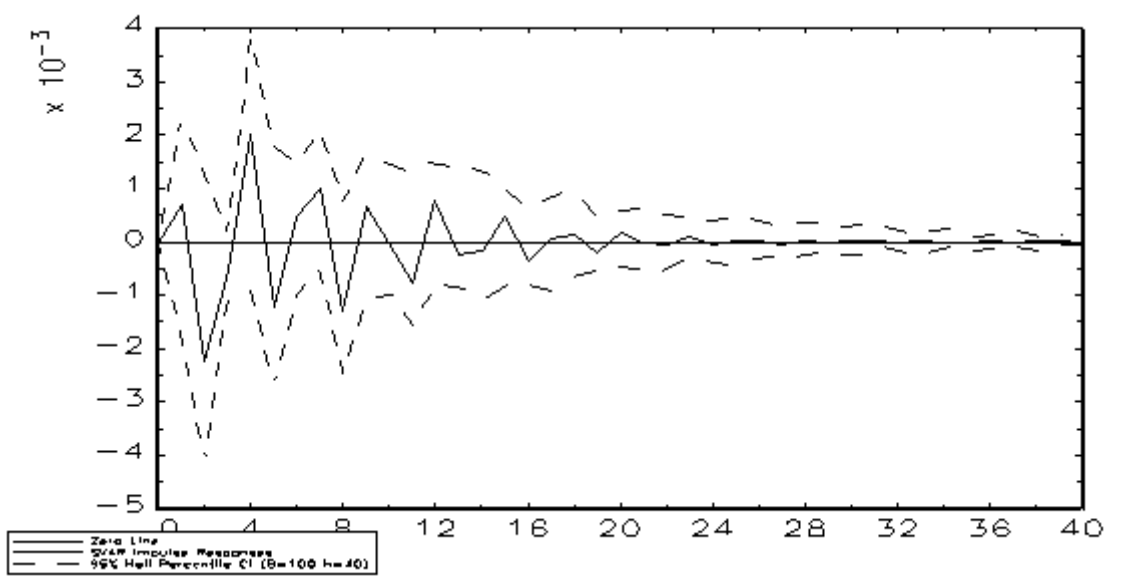

\section{Şekil 9: Reel Döviz Kurunun GSYİH Şoklarına Tepkisi (Senaryo I)}

Kısa vadeli sermaye ise hem reel döviz kuru hem de GSYİH şoklarına pozitif ve artış yönünde tepki vermektedir. Bununla birlikte reel kur şoklarının etkisi daha uzun ve şiddetli olmakta, bu etkiler yaklaşık 20 çeyrek yıl sürmektedir. Buna karşı1ık GSYİH şokları altıncı çeyrekten sonra hafiflemekte ve 16 çeyrekten sonra tamamen sönmektedir. Bir başka önemli nokta her iki şokun kısa vadeli sermaye üzerinde kalıcı etkiler yaratmamasıdır. Böylece sıcak para hareketleri reel ekonomik olgulardan bağımsız hareket sergilemektedir denilebilir (Şekil 10 ve 11$)$.

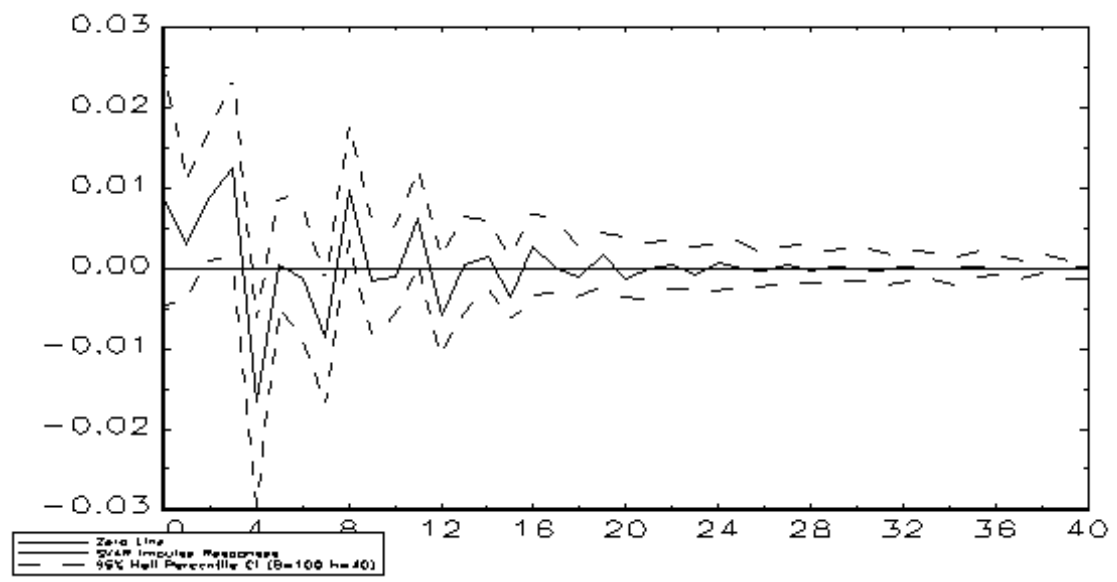

Şekil 10: Kısa Vadeli Sermayenin

Reel Döviz Kuru Şoklarına Tepkisi (Senaryo I) 


\section{(2017) Cilt 1(1)}

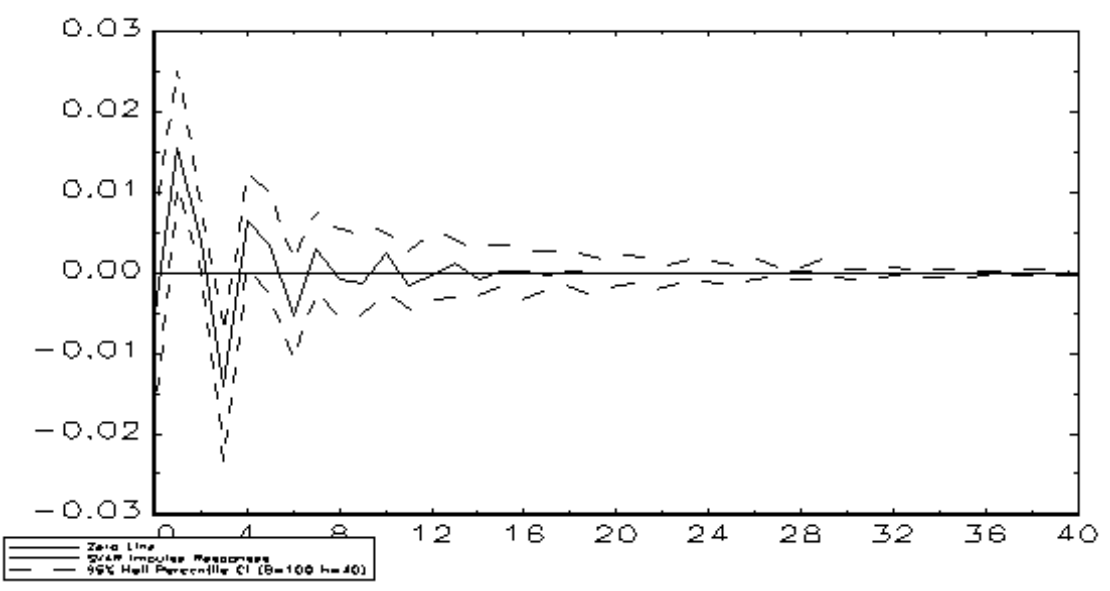

\section{Şekil 11: Kısa Vadeli Sermayenin GSYIH Şoklarına Tepkisi (Senaryo I)}

Değişkenler arasındaki etkileşim, öngörü hatasının varyans ayrıştırması verileriyle de desteklenmektedir.

Örneğin Tablo 10'da özetlenen kısa vadeli sermaye hareketlerindeki dalgalanmalarda şokların paylarına bakıldığında, reel kur şoklarının payı giderek artarken GSYİH şokunun payı yüzde 12 düzeyinde gerçekleşmektedir.

GSYİH şokları reel kur üzerinde yok denecek kadar küçük bir paya sahipken, kısa vadeli sermayenin payı giderek artmakla birlikte görece yine düşük düzeylerdedir. Diğer bir ifade ile reel kur büyük ölçüde kendi şoklarından etkilenmektedir.

GSYİH ayrıştırmasına bakıldığında, burada GSYİH'daki dalgalanmalar büyük ölçüde geçerli olmakla birlikte hem sıcak paranın hem de reel döviz kurunun etkileri söz konusudur. Burada dikkat çeken husus kısa vadeli sermaye, reel döviz kuru ve GSYİH arasındaki karşılıklı etkileşimin varlığıdır. 
(2017) Cilt 1(1)

Tablo 10: Senaryo I Varyans Ayrıştırması

\begin{tabular}{|c|c|c|c|c|}
\hline \multirow{2}{*}{ Değişkenler } & \multirow{2}{*}{ Dönemler } & \multicolumn{3}{|c|}{ ŞOKLAR } \\
\hline & & Sicak Para & Reel Kur & GSYiH \\
\hline \multirow{5}{*}{ Sıcak Para } & 1 & 98 & 02 & 0 \\
\hline & 4 & 88 & 02 & 10 \\
\hline & 8 & 76 & 11 & 13 \\
\hline & 12 & 73 & 15 & 12 \\
\hline & 24 & 71 & 17 & 12 \\
\hline \multirow{5}{*}{$\begin{array}{l}\text { Reel Döviz } \\
\text { Kuru }\end{array}$} & 1 & 01 & 99 & 0 \\
\hline & 4 & 05 & 94 & 01 \\
\hline & 8 & 07 & 92 & 01 \\
\hline & 12 & 08 & 91 & 01 \\
\hline & 24 & 09 & 90 & 01 \\
\hline \multirow{5}{*}{ GSYiH } & 1 & 06 & 0 & 94 \\
\hline & 4 & 08 & 17 & 75 \\
\hline & 8 & 11 & 22 & 67 \\
\hline & 12 & 12 & 22 & 66 \\
\hline & 24 & 12 & 22 & 66 \\
\hline
\end{tabular}

\section{Senaryo II}

Çalışmamızın bu bölümünde Klasik geleneğin varsayımlarına uygun olarak belirlenen kısıtlar çerçevesinde uzun dönem kısıtlı SVAR modeli tahmin edilmiştir. Hatırlanacağı gibi bu gelenekte parasal değişkenlerin reel değişkenler üzerinde uzun dönemde kalıcı etkiler yaratmayacağ1, uzun dönemli etkilerin sadece reel değişkenler tarafindan yaratılacağ savunulur. $\mathrm{Bu}$ çerçevede belirlenen SVAR modeli matris formunda aşağıdaki gibi gösterilebilir: 


\section{(2017) Cilt 1(1)}

$$
\left[\begin{array}{c}
d l s p_{t} \\
\text { dlrdks }_{t} \\
\text { dlgdps }_{t}
\end{array}\right]=\left[\begin{array}{ccc}
C_{11}(L) & C_{12}(L) & 0 \\
0 & C_{22}(L) & 0 \\
0 & C_{32}(L) & C_{33}(L)
\end{array}\right]\left[\begin{array}{l}
\varepsilon_{1 t} \\
\varepsilon_{2 t} \\
\varepsilon_{3 t}
\end{array}\right]
$$

Buna göre reel döviz kuru sadece kendi şoklarından etkilenirken, hem sıcak para hem de GSYİH'yı etkilemektedir. Dolayısıyla sıcak para reel döviz kuru ve GSYİH üzerinde herhangi bir etki yaratmamaktadır. Bu çerçevede hesaplanan kısa $[C(0)]$ ve uzun dönem $[C(L)]$ etki-tepki fonksiyonları aşağıdaki gibidir:

$$
\begin{aligned}
& \varepsilon_{s p} \quad \varepsilon_{r d k} \quad \varepsilon_{g d p} \\
& C(0)=\left[\begin{array}{r}
d l s p_{t} \\
d l r d k s_{t} \\
d l g d p s_{t}
\end{array}\right]=\left[\begin{array}{rrr}
0.0643 & 0.0365 & 0.0049 \\
-0.0103 & 0.0577 & -0.0101 \\
-0.0096 & 0.0038 & 0.0227
\end{array}\right]
\end{aligned}
$$

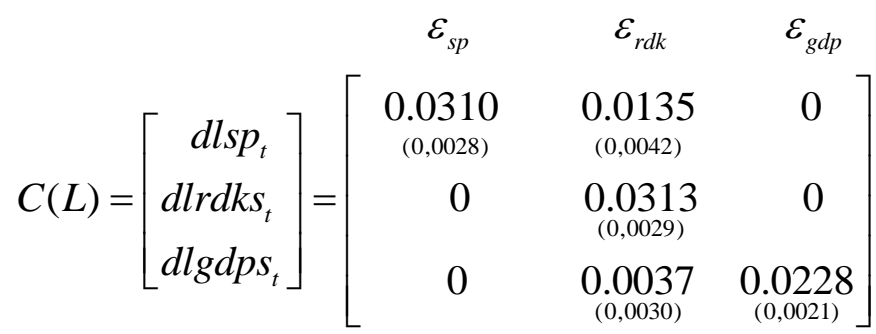

Bu sonuçlara göre, sıcak para hem kendi şoklarına hem de diğer şoklara kısa dönemde pozitif yönde tepki vermektedir. Yani örneğin kısa vadeli sermaye girişi veya reel kurdaki yükselme (TL'nin değerlenmesi) ve ekonomik büyüme sıcak para girişlerine yol açmaktadır. Buna karşın reel döviz kuru kendi şoklarına pozitif yönde tepki verirken sıcak para ve ekonomik büyümenin anlık etkisi negatif yönde olmaktadır. GSYİH ise reel kur ve kendi şoklarından pozitif yönde etkilenirken sıcak paranın anlık etkisi negatif olmaktadır. Uzun dönemli etkilere bakıldığında reel döviz kuru hem kısa vadeli sermayeyi hem de ekonomik büyümeyi pozitif yönde ve kalıcı olarak etkilemektedir. Değişkenlerin şoklar karşısında izlediği zaman patikaları Şekil 18, 19 ve 20'de özetlenmiştir. 


\section{(2017) Cilt 1(1)}

GSYİH reel döviz kuru şoklarından pozitif ve artış yönünde etkilenirken şokların etkisi yaklaşık 15 çeyrek sürdükten sonra sönmekte ve kalıcı bir etki ortaya koymaktadır. Buna karşın kısa vadeli sermaye şoku anlık olarak negatif ve fakat artış yönünde bir etki ortaya koymakta, görece daha hafif olan bu etkiler 10 çeyrek yıl sonra sönmekte ve daha uzun dönemde tamamen ortadan kalkmaktadır (Şekil 12).

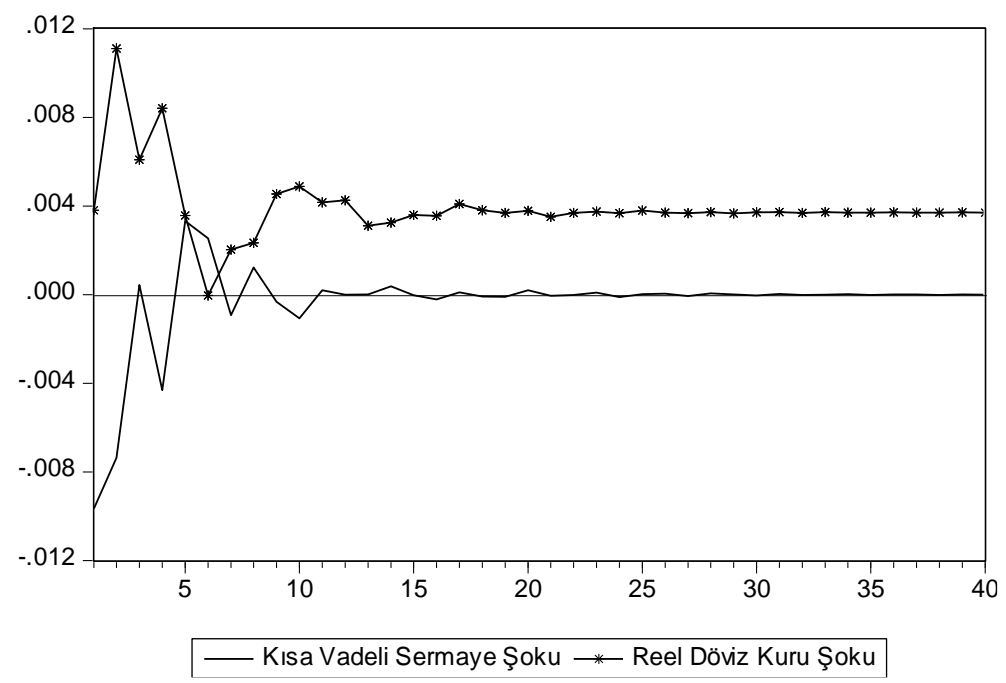

\section{Şekil 12: GSYİH'nın Şoklara Tepkisi (Senaryo II)}

Reel döviz kuru ise her iki şoka anlık olarak negatif ve artış yönünde tepki vermekte ve oldukça dalgalı bir seyir izlemektedir. Her iki şokun reel kur üzerindeki etkisi yaklaşık 25-30 çeyrek yıl sürmekte ve sonra tamamen sönmektedir. Bir başka değişle kısa vadeli sermaye ve GSYIHH kalıcı etkiler ortaya koymamaktadır (Şekil 13). Kuşkusuz bu sonuçta klasik geleneğin düşüncelerine yönelik yapılan varsayımların etkisi de söz konusudur. Buna rağmen söz konusu etkilerin 5-6 yıl devam ediyor olması hiç de küçümsenecek bir durum değildir. 


\section{(2017) Cilt 1(1)}

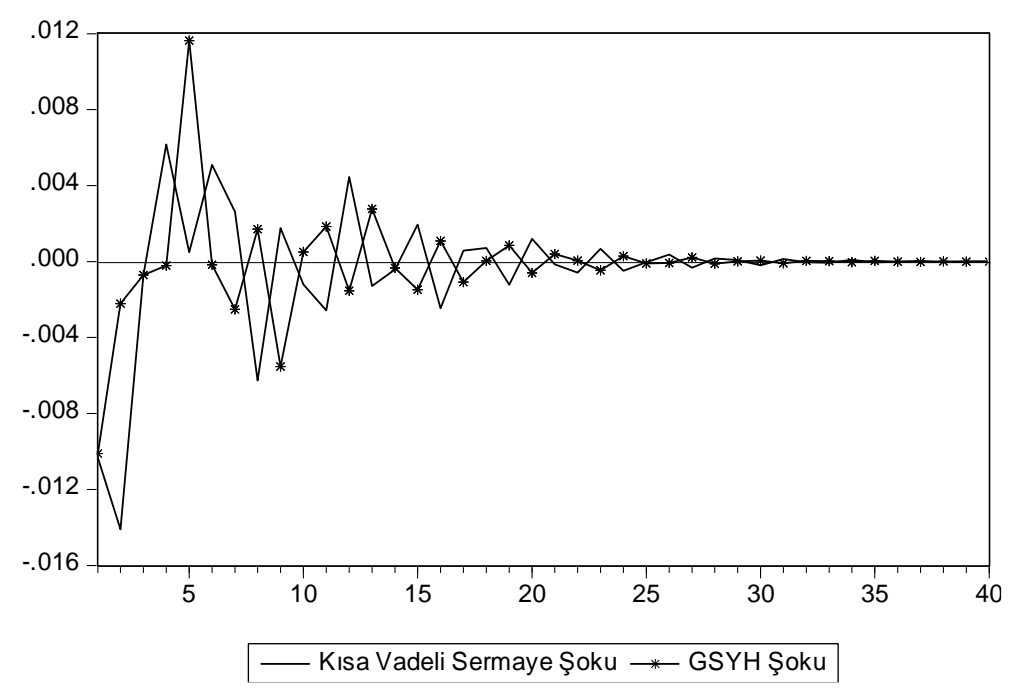

Şekil 13: Reel Döviz Kurunun Şoklara Tepkisi (Senaryo II)

Kısa vadeli sermayeye yönelik etki-tepki fonksiyonlarına bakıldığında ise her iki şokun önemli etkiler yarattığ 1 , buna karşılık kısa vadeli sermayenin reel kur şoklarından kalıcı olarak etkilendiği görülür (Şekil 14).

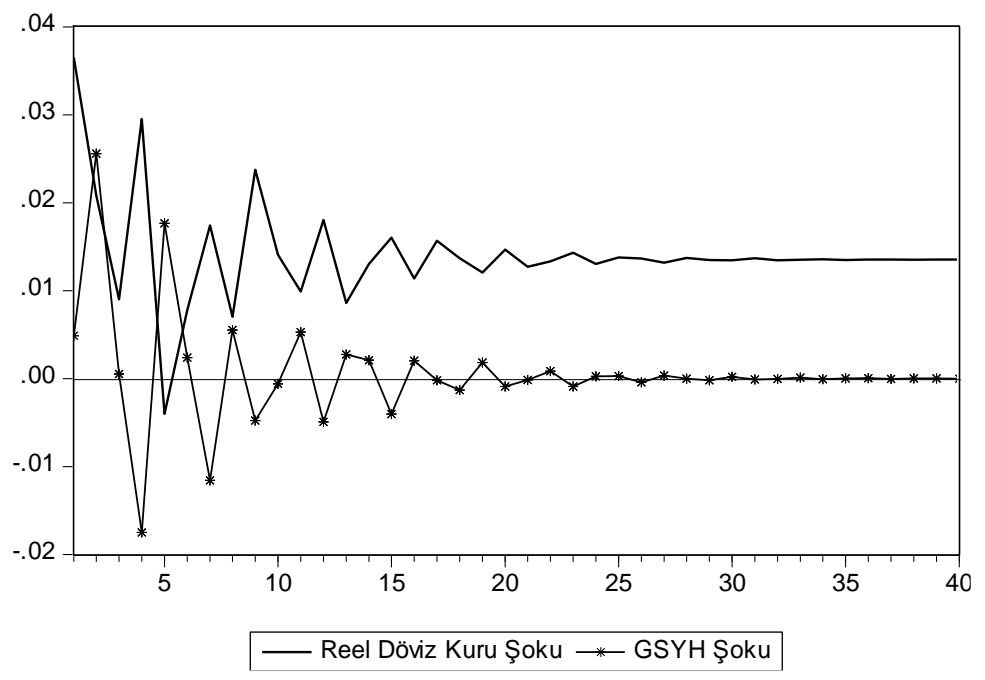

Şekil 14: Kısa Vadeli Sermayenin Şoklara Tepkisi (Senaryo II)

Sonuç olarak, her iki senaryo çerçevesinde değişkenlerin birbirleri üzerinde hatırı sayılır etkilere sahip olduğu söylenebilir. Sicak paradan reel kur ve büyüme, büyümenin reel döviz kuru ve sıcak para üzerinde gösterdiği etkiler ve değişkenlerde gözlenen dalgalanmalar, Klasik dikotominin geçerli olmadığı görüşünü desteklemektedir. Sıcak paranın reel döviz 


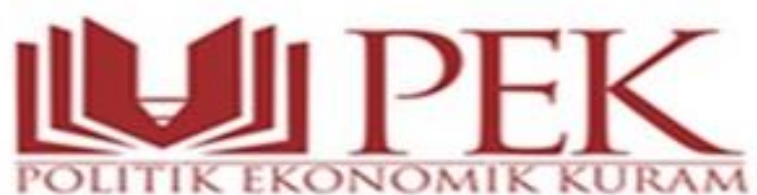

\section{(2017) Cilt 1(1)}

kuru ve GSYİH üzerindeki etkileri ile reel kur-GSYİH ilişkileri bir arada ele alındığında, uzun dönem kısıtlı modellerde, sıcak paranın hem doğrudan hem de "döviz kuru kanalı" olarak ifade edilen mekanizma aracılı̆̆ıla konjonktürel dalgalanmalara neden olduğu söylenebilir.

Sıcak paranın reel kur aracılığıyla dolaylı etkilerinin Senaryo II'de daha kısmi kalması, sıcak para şoklarının reel kur kaynaklı etkileri hafifletmesinden kaynaklanabilir. Zira bu modelde reel kur şoklarının sıcak para üzerindeki etkileri, varsayım gereği dikkate alınmamıştır. Kısaca toparlanacak olursa, Türkiye ekonomisinin sıcak paraya bağımlılı̆̆ının gittikçe arttığı, sıcak paranın genel olarak ekonomi üzerinde önemli ve kalıcı etkiler ortaya koyduğu rahatlıkla ifade edilebilir.

Tahminin hata varyans ayrıştırması, Senaryo I ile karşılaştırıldığında oldukça dikkat çekici sonuçlar ortaya koymuştur. Her şeyden önce kısa vadeli sermayenin varyans ayrıştırmasına bakıldığında hem reel döviz kurunun hem de GSYİH'nın paylarında önemli artışlar söz konusudur. Kisa vadeli sermaye hareketlerinde gözlenen dalgalanmalarda reel kur ve GSYİH'nin payları yüzde 20'ler düzeyine çıkmıştır. Benzen şekilde reel kurdaki dalgalanmalarda özellikle GSYİH'nın payında önemli artışlar gözlenmiştir. Senaryo I'de reel kur üzerinde yüzde 1'ler düzeyinde paya sahip olan GSYİH, burada yüzde 10 seviyelerine çıkmıştır. Reel kur üzerinde kısa vadeli sermayenin payında da kısmi bir artış söz konusu olmuştur. Senaryo II'de göze çarpan en önemli farklardan biri, GSYİH dalgalanmalarında kısa vadeli sermaye payının artıp reel kur ve GSYİH paylarının düşmesidir. Kısa vadeli sermayenin GSYİH dalgalanmasındaki payı yüzde 30'lara ulaşırken reel döviz kurunun payı yüzde 15 civarındadır. 


\section{(2017) Cilt 1(1)}

Tablo 11: Senaryo II Varyans Ayrıştırması

\begin{tabular}{|c|c|c|c|c|}
\hline \multirow{2}{*}{ Değişkenler } & \multirow{2}{*}{ Dönemler } & \multicolumn{3}{|c|}{ ŞOKLAR } \\
\cline { 2 - 5 } & & Sıcak Para & Reel Kur & GSYiH \\
\hline \multirow{5}{*}{ Sıcak Para } & 1 & 75,3 & 24,2 & 0,43 \\
& 4 & 71,3 & 17,2 & 11,3 \\
& 12 & 60,3 & 20,5 & 18,5 \\
& 24 & 59,6 & 21,4 & 19,0 \\
& 1 & 59,2 & 21,5 & 19,3 \\
\hline \multirow{3}{*}{ Reel Döviz } & 4 & 3,0 & 94,1 & 2,9 \\
& 8 & 8,8 & 87,0 & 4,2 \\
& 12 & 9,0 & 82,0 & 9,0 \\
& 24 & 10,4 & 79,8 & 9,8 \\
& 1 & 11,5 & 78,3 & 10,2 \\
\hline \multirow{3}{*}{ GSYru } & 4 & 15,0 & 2,3 & 82,7 \\
& 8 & 22,6 & 12,2 & 65,2 \\
& 12 & 27,7 & 15,0 & 57,3 \\
& 24 & 27,9 & 15,4 & 56,7 \\
& 24 & 27,8 & 15,5 & 56,7 \\
\hline
\end{tabular}

Özet olarak, iki senaryo çerçevesinde ele aldığımız uzun dönem kısıtlı SVAR modeline göre, genel olarak sıcak paranın büyük ölçüde kendi şokları nedeniyle dalgalandığı; reel döviz kuru üzerinde diğer şokların kısmen de olsa etkili olduğu; GSYİH üzerinde hem kısa vadeli sermaye hem de reel döviz kurunun birlikte etkili olduğu söylenebilecektir. Her iki senaryoda kısa vadeli sermayenin önemli etkiler ortaya koyması ve değişkenlerin birbirlerini açıklama gücüne sahip olması, Klasik öngörülerden çok Keynesyen ve Marksist düşünceleri burada da destekler niteliktedir. 


\section{(2017) Cilt 1(1)}

\section{Değerlendirme ve Sonuç}

1980'li yıllarda finansal serbestleşme süreciyle birlikte pek çok ülkede peş peşe yaşanan krizler, iktisat yazınında öteden beri en tartışmalı alanlardan birini oluşturan iktisadi dalgalanmalar konusunu gündeme getirmiş, kısa vadeli sermaye hareketlerinin bu süreçteki rolünün tartışılmasına yol açmışırı.

İktisat okullarının konuya yaklaşımları temelde parayla ilgili kabullerine bağlı olarak şekillenmektedir.

$\mathrm{Bu}$ çerçevede paranın sadece bir araç olduğu kabul edilen Klasik iktisat geleneğini sürdüren okullarda, kısa vadeli sermaye hareketlerinin serbestleştirilmesinin özellikle gelişmekte olan ülkelerdeki konjonktürel dalgalanmaları düzleştireceği, bu ülkelerin rekabet gücünü artırarak istikrarlı bir büyüme yaratacağı iddia edilmektedir.

Buna karşın Keynesyen ve Marksist iktisat geleneklerinde tam tersi görüşler ileri sürülür. Paranın bir servet biriktirme aracı olma özelliğine vurgu yapılan Keynesyen iktisat geleneğinde, bilhassa finansal piyasa aksaklıklarına bağlı olarak sermaye hareketliliğinin iktisadi dalgalanmaları şiddetlendireceği, ticareti yapılamayan sektörler lehine bir sonuç ortaya koyacağ 1 için sektörel asimetrileri olumsuz yönde etkileyeceği savunulur. Marksist gelenekte ise paranın sermaye olduğuna dikkat çekilerek, ekonominin gelişme süreciyle birlikte para sermayenin finansal piyasalarda giderek egemenlik kuracağ 1 , bu sistem içinde paranın giderek kendini bir amaç olarak göreceği ve böylece reel ve parasal kesimlerin birbirinden uzaklaşacağ 1 ifade edilir.

Çalş̧mada sermaye hareketlerinin konjonktür üzerindeki etkilerinin hangi kuramsal görüşle örtüştüğ̈̈, iki ayrı senaryo çerçevesinde analiz edilmiştir. Elde edilen bulgular ışığında kısa vadeli sermaye hareketlerinin ekonomi üzerinde her iki senaryo altında önemli reel etkilere sahip olduğu tespit edilmiş̧ir. Söz konusu etkilerin uzun dönemde kalıcı bir yapı sergilemesi, paranın reel ekonomiyi uzun dönemde etkilemeyeceği şeklindeki Klasik dikotomi görüşünü yanlışlar niteliktedir. Zira sıcak para hareketleri ekonomiyi hem doğrudan hem de reel döviz kuru aracılığıyla kalııı bir şekilde etkileyebilmektedir. Reel değişkenlerin kısa vadeli sermaye üzerindeki etkileri de dikkate alındığında, değişkenler arasındaki karşılıklı etkileşim, 


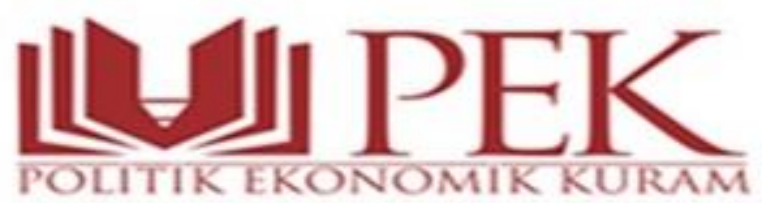

\section{(2017) Cilt 1(1)}

Keynesyen ve Marksist geleneklerde ifade edilen ekonomideki istikrarsılıkların piyasa mekanizması tarafından içsel bir şekilde yaratılacağı görüşünü desteklemektedir.

Kısa vadeli sermayenin reel ekonomi üzerindeki dolaysız etkileri ile sıcak para-reel döviz kuru-büyüme arasındaki karşılıklı etkileşimlerin varlığı, paranın, ekonominin farklı kesimlerinde farklı anlamlara geldiği gerçeğinin dikkate alınmasını gerektirmektedir. Zira para her ekonomik birim için farklı anlamlar taşımaktadır.

Örneğin işçiler için para, çoğunlukla tek gelir kaynağıdır ve yaşamlarını sürdürmek, temel ihtiyaçlarını karşılamak için onu talep etmektedirler. Yani Klasik gelenekte ifade edildiği gibi, para sadece işlem amaçlı talep edilen bir değişim aracı olmaktadır. Ancak aynı şey örneğin firma ve bankalar için geçerli değildir. Zira burada para, bir yandan doğrudan fayda sağlayan tüketim mallarının satın alınmasında kullanılan değişim aracı rolünü yerine getirmekte, diğer yandan kullanım değeri üreten emek, makine-teçhizat gibi üretim faktörlerinin satın alınmasında kullanılmaktadır. Yani kapitalistler için para, kullanım değeri üreten bir şeydir aslında. Diğer bir ifade ile para, hem dolaysız hem de dolaylı fayda sağlayan bir araçtır. Dolayısıyla kapitalistler açısından bakıldığında, kendi geçimi için gerekli miktar çıktıktan sonra kalan miktarın her defasında çoğalıyor olması gerekir. Aksi halde üretimin genişlemesi veya büyüme sürecinin devamlılı̆̆ı söz konusu olamayacaktır.

Bankacılık ve finans kesimi açısından bakıldığında durum bambaşka bir hal almaktadır. Zira bu kesimler açısından kullanım değeri ve değişim değeri üreten tek meta paradır. Para, hem bir tüketim hem de sermaye malıdır burada. Üretilen tek mal para iken, paranın daha fazla üretiliyor olması gerekir ki bu, söz konusu kesimlerin varlık nedenini oluşturmaktadır.

Paranın tüm bu yönleri dikkate alındığında, kısa vadeli sermaye hareketlerinin serbestleştirilmesinin Klasik gelenekteki beklentilerin aksine bir sonuç ortaya koyması şaşırtıcı değildir.

Bu noktada yapılması gereken şeyin başında, paranın reel üretimle olan ilişkisinin sağlam bir temele dayandırılması gerektiği söylenebilir. Bir başka deyişle Klasik gelenekte öngörüldüğü gibi, paranın gerçekten sadece üretim ilişkilerini kolaylaştıran bir araç olmasını sağlayacak önlemler araştırılmalıdır. Bu çerçevede kısa vadeli sermaye giriş-çıkışlarının belirli sürelerle 
sınırlandırılması, kontrol edilmesi vergilendirilmesi, bankacılık kesiminin sıkı denetim altında tutulması gibi önlemler düşünülebilir. Ancak para sermayenin gücünü giderek artırdığı bir küreselleşme sürecinde bu türden önlemlerin sadece bir ‘öneri’ olarak kalma olasılığı oldukça yüksek görünmektedir. Zira rasyonel hareket eden para sermaye sahiplerinin, bu tür müdahalelerin söz konusu olmadığı küresel piyasaları tercih edeceklerini tahmin etmek hiç de zor değildir. Dolayısıyla Türkiye gibi sıcak para girişlerine sürekli olarak ihtiyaç duyulan ekonomilerde bu tür önlemlerin uygulama şansının çok düşük olduğu gün gibi ortadadır.

\section{Yararlanılan Kaynaklar}

Agenor, P.-R., C. J. McDermott, and E. M. Ucer, (1997) "Financial Imbalances, Capital Inflows, and the Real Exchange Rate: The Case of Turkey." European Economic Review, no.41, pp. 819- 825 .

Akyüz, Y. ve K. Boratav (2002), The Making of the Turkish Financial Crisis", UN Conference on Trade and Development, Discussion Papers, No. 158.

Alper, C. E. (2000), "Stylized Facts of Business Cycles, Excess Volatility and Capital Flows: Evidence from Mexico and Turkey”, IV. ODTÜ Ekonomi Konferansı, 14 Eylül, Ankara.

Alper, C. E. (2000), "Stylized Facts of Business Cycles, Excess Volatility and Capital Flows: Evidence from Mexico and Turkey", IV. ODTÜ Ekonomi Konferansı, 14 Eylül, Ankara.

Altunoğlu, A. E. ve B. Güloğlu (2002), "Finansal Serbestleşme Politikaları ve Finansal Krizler: Latin Amerika, Meksika, Asya ve Türkiye Krizleri”, İstanbul Üniversitesi SBF Dergisi, No. 27.

Amisano, G. \& C. Giannini (1997), Topics in Structural VAR Econometrics, Second Edition, Springer-Verlag, Berlin, Germany. 


\section{(2017) Cilt 1(1)}

Apaydın, Ş. (2015a), Türkiye'de Kısa Vadeli Sermaye Hareketlerinin İktisadi Dalgalanmalar Üzerindeki Etkileri, (Yayımlanmamış Doktora Tezi), Ankara Üniversitesi Sosyal Bilimler Enstitüsü, Ankara.

Apaydın, Ş. (2015b), Adam Smith'ten Günümüze Kriz ve Konjonktür Kuramları, Nota Bene Yay., Ankara.

Arestis, P. ve M. Glickman (2002), "Financial Crisis in Southeast Asia: Dispelling Illusion the Minskyan Way", Cambridge Journal of Economics, 26, pp. 237-260.

Arın, T. (2003), “Türkiye'de Mali Küreselleşme ve Mali Birikim ile Reel Birikimin Birbirinden Kopması", içinde Köse, A. H., F. Şenses ve E. Yeldan (Der.), İktisat Üzerine Yazlar I - Küresel Düzen: Birikim, Devlet ve Sinıflar: Korkut Boratav'a Armağan, İletişim Yay., İstanbul, ss. 93-141.

Arrighi, G. (2000), Uzun Yirminci Yüzyıl: Para, Güç ve Çağımızın Kökenleri, (Çev. Recep Boztemur), 1. B., İmge Kitabevi, Ankara.

Aslan, N., Terzi, N. Ve Siampan, E. (2014), “Türkiye'de Kısa Vadeli Sermaye Hareketlerinin Ekonomik Büyüme ve Reel Döviz Kuru ile İlișkisi”, Finansal Araștırmalar ve Çalışmalar Dergisi, C. 5, S. 10, ss. 15-32.

Balkan, E., Biçer, F. Gül ve E. Yeldan (2002), "Patterns of Financial Capital Flows and Accumulation in the Post-1990 Turkish Economy", www.bilkent.edu.tr/ yeldane/BBYmetu2002-2.pdf.

Bernanke, B. (1986), “An Alternative Explanations of Money-Income Correlation”, NBER Working Papers, No: 1842.

Beveridge, S. \& C. Nelson (1981), “A New Approach to Decomposition of Economic Time Series into Permanent and Transitory Components with Particular Attention to Measurement of the Business Cycle", Journal of Monetary Economics, Vol 7, March, pp. 151-174. 


\section{(2017) Cilt 1(1)}

Blanchard, O. J. \& D. Quah (1989), “The Dynamic Effects of Aggregate Demand and Supply Disturbances”, American Economic Review, Vol. 79, No: 4, pp. 655-673.

Blaug, M. (1978), Economic Theory in Retrospect, Third Ed., Cambridge University Press, Cambridge, USA.

Boratav, K. (1993), "External Financial Liberalization in Developing Countries: Some Adverse Consequences”, ODTÜ Gelişme Dergisi, C.20, S.1-2:1-17.

Boratav, K. (1995), “İktisat Tarihi 1981-1994”, Bugünkü Türkiye 1980-1995, Der. Sina Akşin, C.5 : 159-213.

Boratav, K. (2000), Yeni Dünya Düzeni: Nereye?, İmge Kitabevi Yay., Ankara.

Boratav, K. (2001), “2000/2001 Krizinde Sermaye Hareketleri” İktisat, İşletme ve Finans, S. 186, Eylül, ss. 7-17.

Boratav, K. (2003), "Yabancı Sermaye Girişlerinin Ayrıştırılması ve Sıcak Para: Tanımlar, Yöntemler, Bazı Bulgular”, içinde Köse, A. H., F. Şenses ve E. Yeldan (Der.), İktisat Üzerine Yazılar II - İktisadi Kalkınma, Kriz ve İstikrar: Oktar Türel'e Armağan, İletişim Yay., İstanbul, ss. 17-30.

Boratav, K. ve E. Yeldan (2001), “Turkey, 1980-2000: Financial Liberalization, Macroeconomic (In)-Stability and Patterns of Distribution”, http://www.bilkent.edu.tr/ yeldane/B\&YCEPA2002.PDF.

Boratav, K., O. Türel ve E. Yeldan (1996), "Dilemmas of Structural Adjustment and Environmental Policies Under Instability: Post-1980 Turkey”, World Development, Vol. 24, No. 2, pp. 373-393.

Breitung, J., R. Brüggemann \& H. Lütkepohl (2004), "Structural Vector Autoregressive Modeling and Impulse Responses”, içinde Lütkepohl, H. \& M. Kratzig (Ed.), Applied Time Series Econometrics, pp. 159-196. 
Çimenoğlu, A. \& N. Yentürk (2002), "Impacts of International Capital Inflows on the Turkish Economy, ODTÜ Ekonomi Kongresi, 11-15 Eylül, Ankara.

Civcir, İ. (2005), "Dollarization and Its Long-run Determinants in Turkey", Middle East Economics Series, Vol. 6, pp. 201-232.

Danışoğlu, A. (1999), "Kısa Vadeli Sermaye Hareketlerinin Gelişmekte Olan Ülkeler ve Türkiye Üzerindeki Etkileri’, (Yayımlanmamış Doktora Tezi, İstanbul Üniversitesi Sosyal Bilimler Enstitüsü), İstanbul.

Davidson, P. (1990), “Keynes and Money”, içinde Roger Hill (Ed.), Keynes, Money and Monetarism, St. Martin's Press, New York, USA, pp. 2-26.

Davidson, P. (1994), Post Keynesian Macroeconomic Theory: A Foundation for Successful Economic Policies for the Twenty-first Century, Edward Elgar Publishing Ltd., England.

Davidson, P. (1998), “The Case for Regulating International Capital Flows”, paper presented at Social Market Foundation Seminar on Regulation Capital Movements, November, London.

Dickey, D. \& W. A. Fuller (1979), "Distribution of the Estimators for Autoregressive Time Series with a Unit Root", Journal of the American Statictical Association, Vol. 74, No: 366, pp. 427-431.

Dickey, D. \& W. A. Fuller (1981), “A Likelihood Ratio Statistics for Autoregressive Time Series with a Unit Root”, Econometrica, Vol. 49, July, pp. 1057-1072.

Dow, S. C. (1986-87), "Post Keynesian Monetary Theory for an Open Economy”, Journal of Post Keynesian Economics, winter, Vol. IX, No. 2, ss. 237-257.

Eichengreen, B., vd., (1999b), "Liberalizing Capital Movements: Some Analytical Issues”, http://www.imf.org/external/pubs/ft/issues/issues 17. 


\section{(2017) Cilt 1(1)}

Enders, W. (1995), Applied Econometric Time Series, John Wiley and Sons, INC., New York.

Gordon, R. A. (1961), Business Fluctuations, 2nd Edition, Harper and Brothers Pub., New York.

Güloğlu, B. (2008), Ekonometri Ders Notları, PAÜ Ekonomi Yaz Seminerleri, Denizli.

Haberler, G. (1946), Prosperity and Depression, United Nations Lake Success, New York, USA.

İnsel, A. ve N. Sungur (2003), "Sermaye Akımlarının Temel Makroekonomik Göstergeler Üzerindeki Etkileri: Türkiye Örneği - 1989:III - 1999:IV”, Türkiye Ekonomi Kurumu Tartışma Metni, 2003/8, http://www.tek.org.tr.

Jiménez, J. F. P. (2001), "Business Cycles In Small Open Economies: The Case Of Costa Rici”, http://www.adlib.iss.n1/adlib/uploads/wp/wp330.

Johansen, S. (1988), "Statistical Analysis of Cointegration Vectors", Journal of Economic Dynamics and Control, Vol. 12, pp.231-254.

Johansen, S. \& K. Juselius (1990), "Maximum Likelihood Estimation and Inference on Cointegration wit Application to the Demand for Money", Oxford Bulletin of Economics and Statistics, Vol. 52, pp.169-209.

Kadılar, C. (2000), Uygulamalı Çok Değişskenli Zaman Serileri Analizi, H. Ü. Fen Fakültesi İstatistik Bölümü, Ankara.

Keynes, J. M. (1921), A Treatise on Probability, Macmillan and Co., Ltd. St. Martin's Street, London.

Keynes, J. M. (1936 [1939]), The General Theory of Employment, Interest and Money, Macmillan and Co., Ltd, London. 
Keynes, J. M. (1937a), “The General Theory of Employment”, The Quarterly Journal of Economics, Vol. 51, No. 2, pp. 209-223.

Köse, A. H. \& A. Öncü (2003), “İktisadın Piyasası, Kapitalizmin Ekonomisi”, içinde Köse, A. H., F. Şenses ve E. Yeldan (Der.), İktisat Üzerine Yazılar I - Küresel Düzen: Birikim, Devlet ve Sınıflar: Korkut Boratav'a Armağan, İletişim Yay., İstanbul, ss. 93-141.

Kregel, J. A. (1998), “Yes, 'It' Did Happen Again - A Minsky Crisis Happened in Asia”, The Jerome Levy Economics Institute Working Paper, No. 234.

Kwiatkowski,D., P. C. B. Phillips, P. Schmidt \& Y. Shin (1992), “Testing the Null Hypothesis of Stationarity Against the Alternative of a Unit Root: How Sure Are We that Economic Time Series Have a Unit Root", Journal of Econometrics, Vol. 54, No: 1-3, October-December, pp. 159-178.

Kydland, F. E. \& E. C. Prescott (1990), "Business Cycles: Real Facts and a Monetary Myth", Federal Reserve Bank of Minneapolis Quarterly Review, Vol. 14, No: 2, pp. 3-18.

Lütkepohl, H. (2005), A New Introduction to Multiple Time Series Analysis, SpringerVerlag, Berlin, Germany.

Mandel, E. (2008), Marksist Ekonomi El Kitabı, 3. Baskı, (Çev. Orhan Suda), Özgür Üniversite Kitaplığı No. 68, Maki Basın Yayın, Ankara.

Marx, K. (1867 [2007]), Kapital, Kapitalist Üretimin Eleştirel Bir Tahlili, Birinci Cilt, (Çev. Alaattin Bilgi), 8. Baskı, Sol Yayınları, Ankara.

Marx, K. (1894 [2006]), Kapital, Ekonomi Politiğin Eleştirisi, Üçüncü Cilt, (Çev. Alaattin Bilgi), 5. Baskı, Sol Yayınları, Ankara.

Minsky, H. P. (1975), John Maynard Keynes, Columbia University Press, USA. 


\section{(2017) Cilt 1(1)}

Minsky, H. P. (1986 [2013]), İstikrarsız Bir Ekonominin İstikrarı, (Çeviren: Oğuz Esen), Efil Yayınevi, Ankara.

Minsky, H. P. (1992), “The Financial Instability Hypothesis”, The Jerome Levy Economics Institute of Bard College Working Paper, No. 74.

Mishkin, F. (1996), "Understanding Financial Crises: A Developing Country Perspective", NBER Working Paper, No. 5600.

Mishkin, F. (1998), "International Capital Mobility, Financial Volatility and Financial Instability", NBER Working Paper, No. 6390.

Mishkin, F. (1999), "Lessons from the Asian Crisis", Journal of International Money and Finance, 18, pp. 709-723.

Mitchell, W. C. (1951), "Business Cycles", içinde Readings in Business Cycle Theory, Richard D. Irwin, Inc., ss.43-60.

Ng, S. and P. Perron (2001), "Lag Length Selection and the Construction of Unit Root Tests with Good Size and Power”, Econometrica, Vol. 69, No: 6, pp. 1519-1554.

Oğuz, H. (1995), "Devresel Dalgalanma Teorileri ve Türk Ekonomisindeki Devresel Dalgalanmalar”, (Yayımlanmamış Doktora Tezi, Hacettepe Üniversitesi Sosyal Bilimler Enstitüsü), Ankara.

Oğuz, H. (1999), “Türk Ekonomisindeki Devresel Dalgalanmalar: Betimsel Bir Çalışma”, H.Ü. İ.İ.B.F. Dergisi, C.17, Say1 1, s. 77-103.

Öncü, A. (2008), “Küreselleşme”, içinde Ekonomik Kurumlar ve Kavramlar Sözlüğü: Eleştirel Bir Giriş, (Ed. Fikret Başkaya ve Aydın Ördek), Özgür Üniversite Yayınları, No. 72, ss. 741-753.

Özatay, F. (1986), “Türkiye Ekonomisinde Devresel Hareketler”, (Yayımlanmamış Doktora Tezi, Ankara Üniversitesi Sosyal Bilimler Enstitüsü), Ankara. 


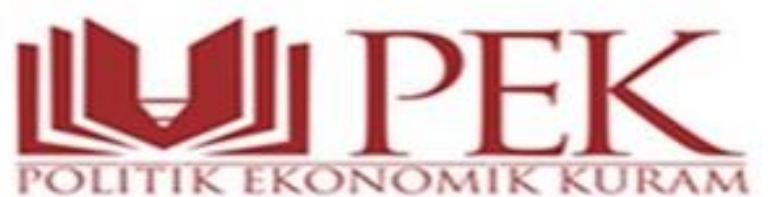

\section{(2017) Cilt 1(1)}

Özatay, Fatih \& Güven Sak (2002), “The 2000-2001 Financial Crisis in Turkey”, http://www.brookings.edu.

Özkan, G. (2003), “Currency and Financial Crises in Turkey 2000-2001: Bad Fundamentals or Bad Luck?", The World Economy, Vol. 28, Issue 4, p.541.

Perron, P. \& Serena Ng, (1996), "Useful Modifications to Unit Root Tests with Dependent Errors and Their Local Asymptotic Properties", Review of Economic Studies, Vol. 63, pp. 435-465.

Persons, W. M. (1926), "Theories of Business Fluctuations", The Quarterly Journal of Economics, Vol. 41, No. 1, November, pp. 94-128.

Phillips, P. C. B. \& Perron, P. (1988), “Testing for a Unit Root in Time Series Regression”, Biometrica, 75, pp. 335-346.

Ricardo, D. (1817 [2007], Ekonomi Politiğin ve Vergilendirmenin İlkeleri, (Çev. Tayfun Ertan), Belge Yay., No. 568, İstanbul.

Schumpeter, J. A. (1954), History of Economic Analysis, Oxford University Press, USA.

Schwert, G. W. (1989), “Tests for Unit Roots: A Monte Carlo Investigation”, Journal of Business and Economic Statisticsk, 7, pp: 147-160.

Shaikh, A. (2009), "Bunalım Kuramlarının Tarihine Giriş", içinde Dünya Kapitalizminin Krizi, (Der. Nail Satligan ve Sungur Savran), Belge Yayınları, No. 600, 2. B., İstanbul, ss. $126-171$.

Sims, C. (1980), “Macroeconomics and Reality”, Econometrica, Vol. 48, No: 1, January, pp. $1-48$.

Sims, C. (1986), “Are Forecasting Models Usable for Policy Analysis?”, Federal Reserve Bank of Minneapolis Quarterly Review”, Winter, pp. 3-16. 


\section{(2017) Cilt 1(1)}

Smith, A. (1776 [2007]), An Inquiry into the Nature and Causes of Wealth of Nations, Metalibri, http://metalibri.incubadora.fapesp.br.

Somçağ, S. (2002), “Türkiye'nin Ekonomik Krizi: Oluşumu ve Çıkış Yolları”, http://www.bagimsizsosyalbilimciler.org/Yazilar_Diger/somcagAgu02.doc.

Stock, J. H. \& M. W. Watson (2001), "Vector Autoregressions", Journal of Economic Perspectives, Vol. 15, No: 4, pp. 101-115.

Tanyılmaz, K. (2002), “Dalgaları Aş(ama)mak: Kapitalizmi Dönemleştirme Teorileri Üzerine Düşünceler", Praksis, 5, 323-356.

Uygur, E. (2001a), "Krizden Krize Türkiye: 2000 Kasım ve 2001 Şubat Krizleri”, Türkiye Ekonomi Kurumu Tartışma Metni, No. 2001/1.

Uygur, E. (2001b), “Türkiye'nin Yürürlüğe Koyduğu İstikrar Programlarının Başarısında Yabancı Sermaye Girişlerinin Yeri ve Önemi”, TCMB Ekonomik İstikrar ve Yabancı Sermaye Semineri, ss. 1287-143.

Yeldan, E. (2001), Küreselleşme Sürecinde Türkiye Ekonomisi, İletişim Yay., İstanbul.

Zarnowitz, V. (1985), "Recent Work on Business Cycles in Historical Perspective: A Review of Theories and Evidence", Journal of Economic Literature, Vol. 23, pp. 523-580.

Zarnowitz, V. (1991), “What is a Business Cycle?”, NBER Working Paper, No. 3863. 